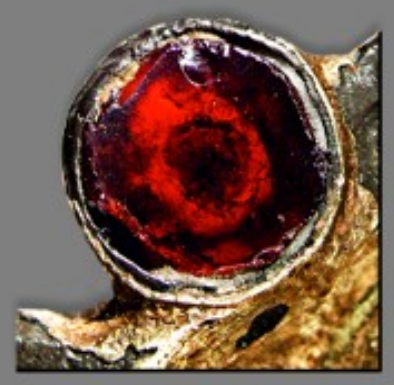

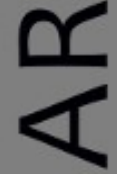

$\sim$

ш
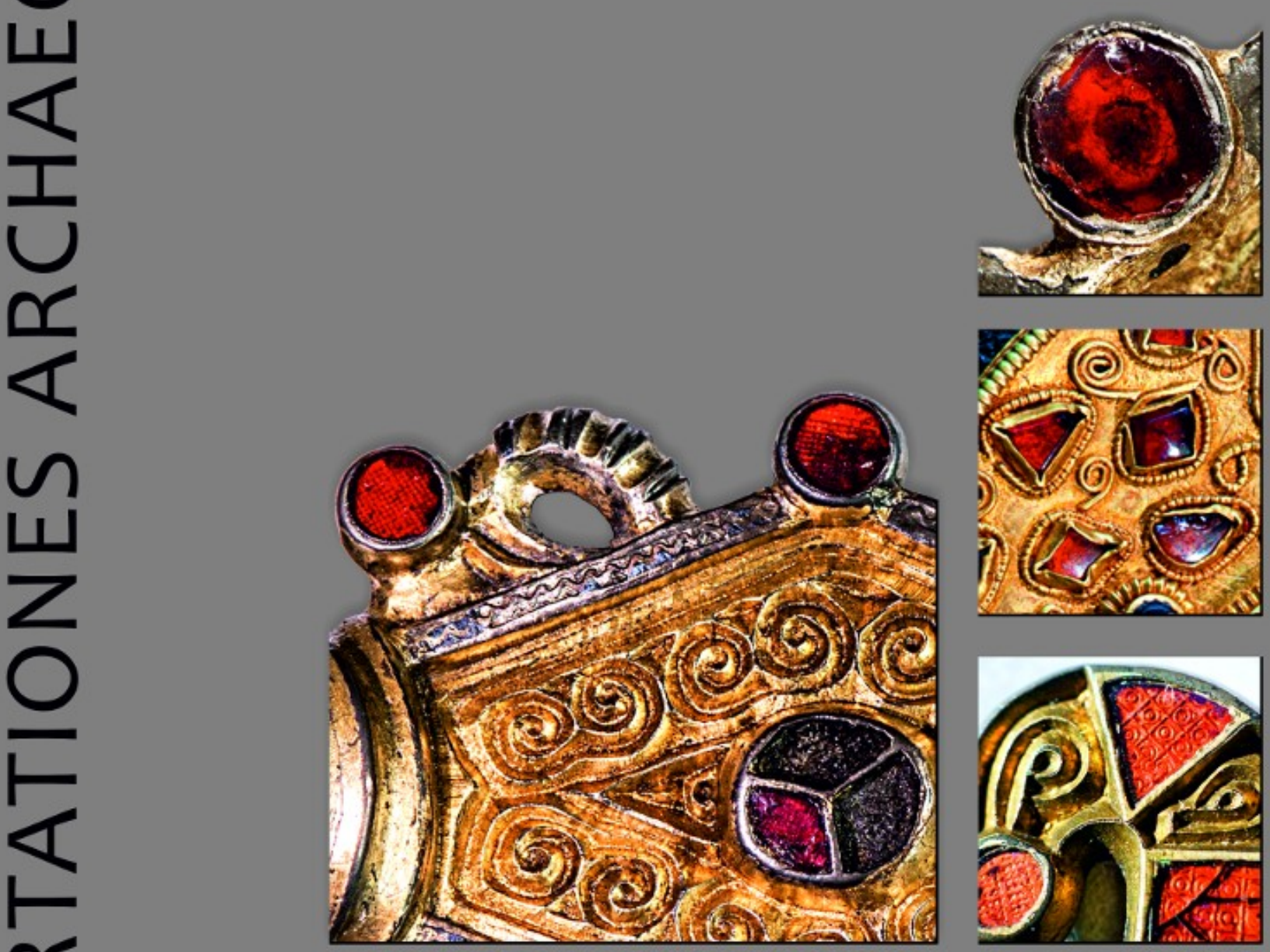

E

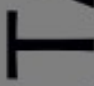

œ

山

n

ก

$\overline{0}$
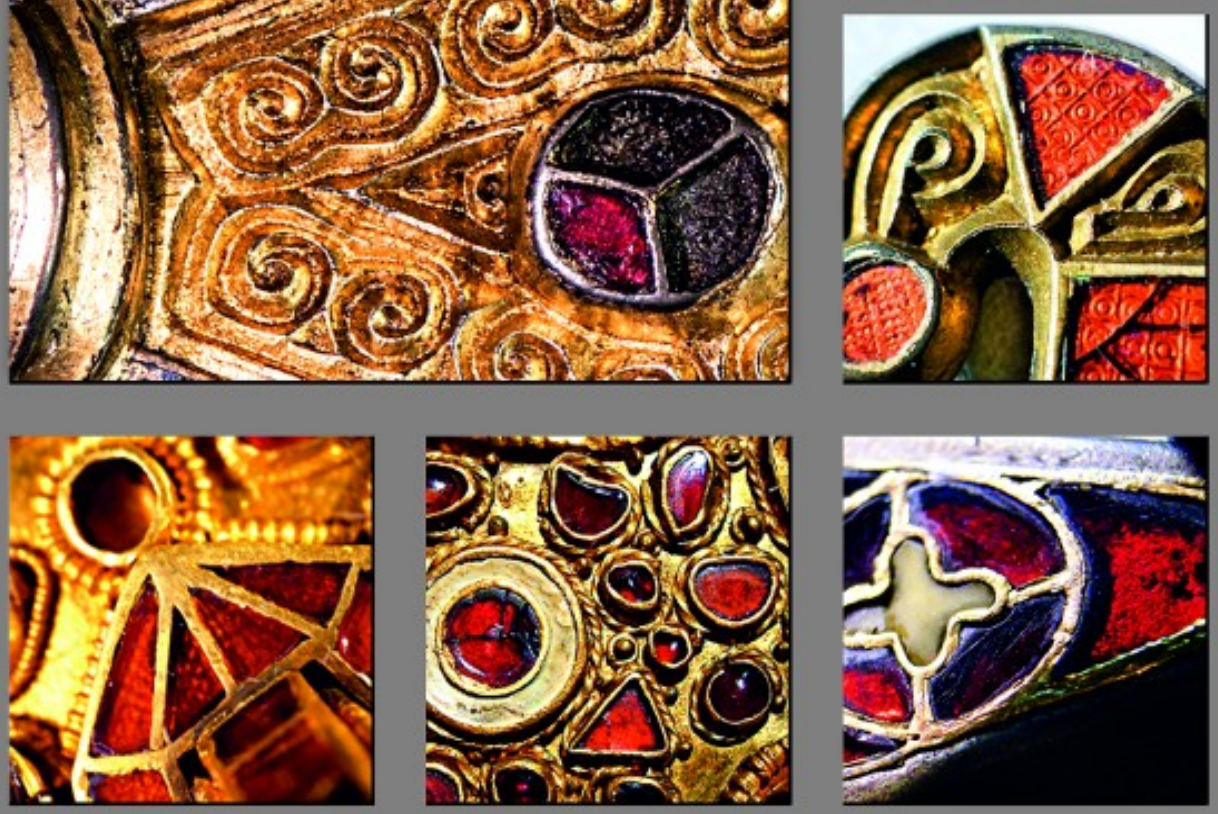

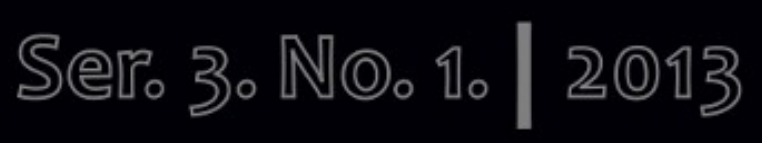




\section{Dissertationes Archaeologicae ex Instituto Archaeologico}

Universitatis de Rolando Eötvös nominatae Ser. 3. No. 1.

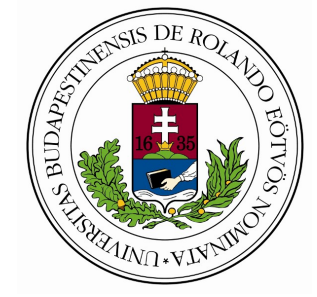

Budapest 2013 
Dissertationes Archaeologicae ex Instituto Archaeologico

Universitatis de Rolando Eötvös nominatae

Ser. 3. No. 1.

Editor-in-chief:

DÁvid BARTUS

Editorial board:

LÁSZLÓ BARTOSIEWICZ

LÁSZLÓ BORHY

ISTVÁN FELD

GÁBOR KALLA

PÁL RACZKY

Miklós SzABÓ

TIVADAR VIDA

Technical editors:

DÁvid BARTuS

GÁBOR VÁCZI

ANDRÁs BöDŐcs

Proofreading:

Zsófia KondÉ

SzILvia SzÖLlősI

Available online at http://dissarch.elte.hu

Contact: dissarch@btk.elte.hu

\section{$\underline{\text { PKP }}$ \\ PUBLIC \\ KNOWLEDGE \\ PROJECT}

(C) Eötvös Loránd University, Institute of Archaeological Sciences

Budapest 2013 


\section{Contents}

\section{Articles}

Melinda TORBÁGYI - István VIDA

The coin hoard of Abasár

Anikó BózsA

21

Roman mirrors from a private collection in the Hungarian National Museum

Lajos JuHÁsz

45

The Biesheim cameo - a reinterpretation

\section{Methods}

Péter CsIPpÁN

$A z$ állatcsont, mint információhordozó leletanyag

Kata DÉvAI

Terminológiai alapfogalmak régészeti korú üvegtárgyak elemzéséhez

Lőrinc TimáR - Zoltán Czajlik - Sándor Puszta - Balázs Holl

$3 D$ reconstructions using GPR data at the Mont Beuvray

\section{FIELD REPORTS}

Zsolt MESTER

Excavation at a new Upper Palaeolithic site of the Eger region (Northern Hungary)

László BORHY - Dávid BARTus - Emese SzÁmadó

Short report on the excavations at Brigetio (Szőny-Vásártér) in 2013

Dénes HulLÁm - Zsófia RÁcz

Report on the participation of the Eötvös Loránd University at the Wielbark Archaeological Field School in Malbork-Wielbark, Poland

Gábor VÁczi - Dávid BARTus

Short report on the excavations at the site Makó - Igási Ugar

Maxim MoRdovin

Short report on the excavations in 2013 of the Department of Hungarian Medieval and Early Modern Archaeology (Eötvös Loránd University, Budapest)

\section{THESIS ABSTRACTS}

Kitti KÖHLER

Biological reconstruction of the Late Neolithic Lengyel Culture 
Cultural connections and interactions of Eastern Transdanubia during the Urnfield period

Orsolya LÁNG

Urban problems in the civil town of Aquincum: the so-called „northern band”

Nikoletta SEY

Questions of bronze workshops in Roman Pannonia

Kata DÉvaI

Glass vessels from Late Roman times found in graves in the Hungarian part of Pannonia

Eszter HORvÁTH

Gemstone and glass inlaid fine metalwork from the Carpathian Basin:

the Hunnic and Early Merovingian Periods

Gergely SzEnTHE

Vegetal ornaments in the Late Avar decorative art

Péter LANGó

Relations between the Carpathian Basin and South East Europe during the 10th century.

The evidence of the minor objects

Ciprián HoRvÁTH

The Cemeteries and Grave Finds of Györ and Moson Counties from the Time

of the Hungarian Conquest and the Early Árpádian Age

András Sófalvi

The border- and self-defence of Szeklers from the Medieval Age till the Age of Principality.

Castles and other defence objects in the settlement history of Udvarhelyszék 


\title{
Gemstone and glass inlaid fine metalwork from the Carpathian Basin: the Hunnic and Early Merovingian Periods
}

\author{
ESZTER HORVÁtH \\ Department of Neutron Spectroscopy \\ Wigner Research Centre for Physics \\ Hungarian Academy of Sciences \\ horvath.eszter@wigner.mta.hu
}

\begin{abstract}
PhD thesis submitted in 2013 to the Archaeology Doctoral Programme, Doctoral School of History, Eötvös Loránd University, Budapest under the supervision of Tivadar Vida.
\end{abstract}

\section{Research Objectives}

The subject of the dissertation is an impressive archaeological material from the Migration Period and Early Medieval Carpathian Basin - the 5th-6th century polychrome fine metalwork. The artefacts under investigation represent the archaeological remains of four main cultural-chronological groups. The discussed period of almost two hundred years covers the Hunnic Period as well as the Periods of the various post-Hunnic Germanic Kingdoms, the Gepidic Kingdom and the Langobardic Kingdom. In the dissertation nearly four hundred pieces of goldsmiths' work have been analysed from more than one hundred sites (aside from stray finds) such as graves, treasures as well as ritual deposits. Functionally they can be labelled as elements of jewellery, garment or different equipment and as other articles for personal use.
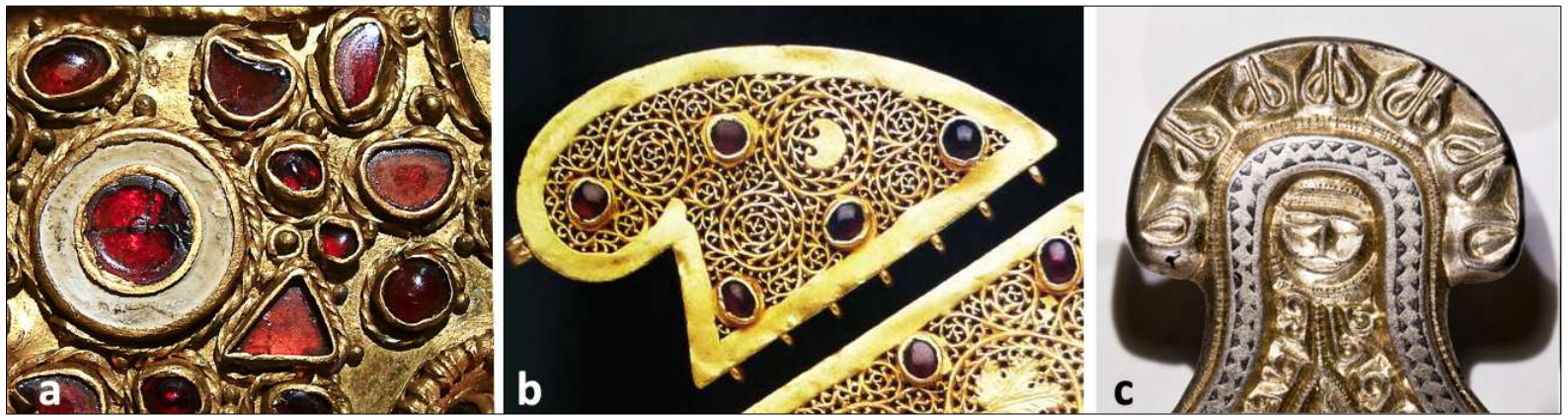

Fig. 1. Goldsmiths' works with polychrome effects: a, gem inlay (Photo: E. Horváth). b, opus interrasile (CHristiE’s 1996, 66). c, chip carving and niello (Photo: E. Horváth).

Prior to my dissertation, the archaeological and art historical research mostly brought the stylistic and ornamental characteristics of this material into focus. The results pointed out that the archaeological styles and the trends of the decorating art represented by the artefacts were not coherent. The only common trait of the discussed metalwork is the polychrome decoration with gemstone or glass inlays (Fig. 1). Therefore, classification of the archaeological material proved to be indispensable, even though the initial purpose of my work was not exactly this. 
The primary goal of the performed analyses was to refine and clarify numerous archaeological questions raised about the production of these goldsmiths' works. As a main issue of my research I have undertaken to interpret the phases, conditions, background and relations of the manufacturing process in a comprehensive, consistent and accurate way. In this investigation I was motivated by the indirect reconstruction of the early medieval goldsmith activity drawing attention to the finished artefacts themselves. In this way I intended to compensate for the scarcity of relevant information on the practice of goldsmiths in Europe and the Mediterranean region as well as on the organisation and scenes of their activity. Concerning the Carpathian Basin, our related knowledge was especially deficient so far.

Studying the material various questions could have been raised. How were these pieces of fine metalwork made, worn and altered? What kind of practice and tradition has driven their production? What kind of equipment, infrastructure and network of contacts served as a base for this? What kind of individual and regional features characterised the production? All these led to the three following primal questions discussed in the dissertation:

- What kind of goldsmithing traditions are represented by the artefacts?

- How was the organisational background of their production?

- What kind of workshop affinities can be revealed regarding their production?

Widespread occurrence of the polychrome art made it necessary to also get familiar with analogies from the neighbouring areas of the Carpathian Basin. Consequently, the observed features were interpreted from a wider perspective. My investigation followed the international research directions and the obtained results got integrated into the European scholarship of the discussed periods.

\section{Methodology}

To be consistent in terminology I have found the most essential expressions used in the dissertation necessary to define. Among fundamental terms I dealt particularly with the meaning of workshop, workshop practice, workshop area, goldsmithing tradition, polychrome style as well as materials technology.

The main features that the investigated artefacts had in common are the polychromy and the composite character (Fig. 2). These two arise from the diversity of the used base-materials and the complexity of the manufacturing process, respectively. The performed analyses required a wider research perspective exceeding the conventional archaeological methods. Descriptions and photos of different quality available in the publications did not prove to be sufficient in the discussion of the above mentioned questions. In order to identify material and technological details related to the production, autopsy, i.e. direct observation of every single object was indispensable. My investigation has been realised in terms of interdisciplinarity; i.e. the relationship of the different research fields and specialities served as its base. ${ }^{1}$ Apart from the archaeology, also the knowledge, methods and experiments of various natural sciences (mineralogy and gemmology, petrography and geochemistry, metallurgy and metallography) as well as of the related handcrafts (gem cutting and goldsmith art) and conservation works had to be taken into consideration.

1 HoRvÁth 2011. 
For the examination I adopted the method of comparative analysis; five fundamental features of the production were considered as a base for this: function, form, ornamentation, base material and manufacturing technique. ${ }^{2}$ The instrumental archaeometric analysis was the other method applied. In this way, I primarily intended to reveal the material and tech nological characteristics of the artefacts as specified as possible. The investigation of the artefacts has been realized as a multistage process at macroscopic, microscopic and largescale analytical levels. Scientific analyses were performed or controlled personally by myself.

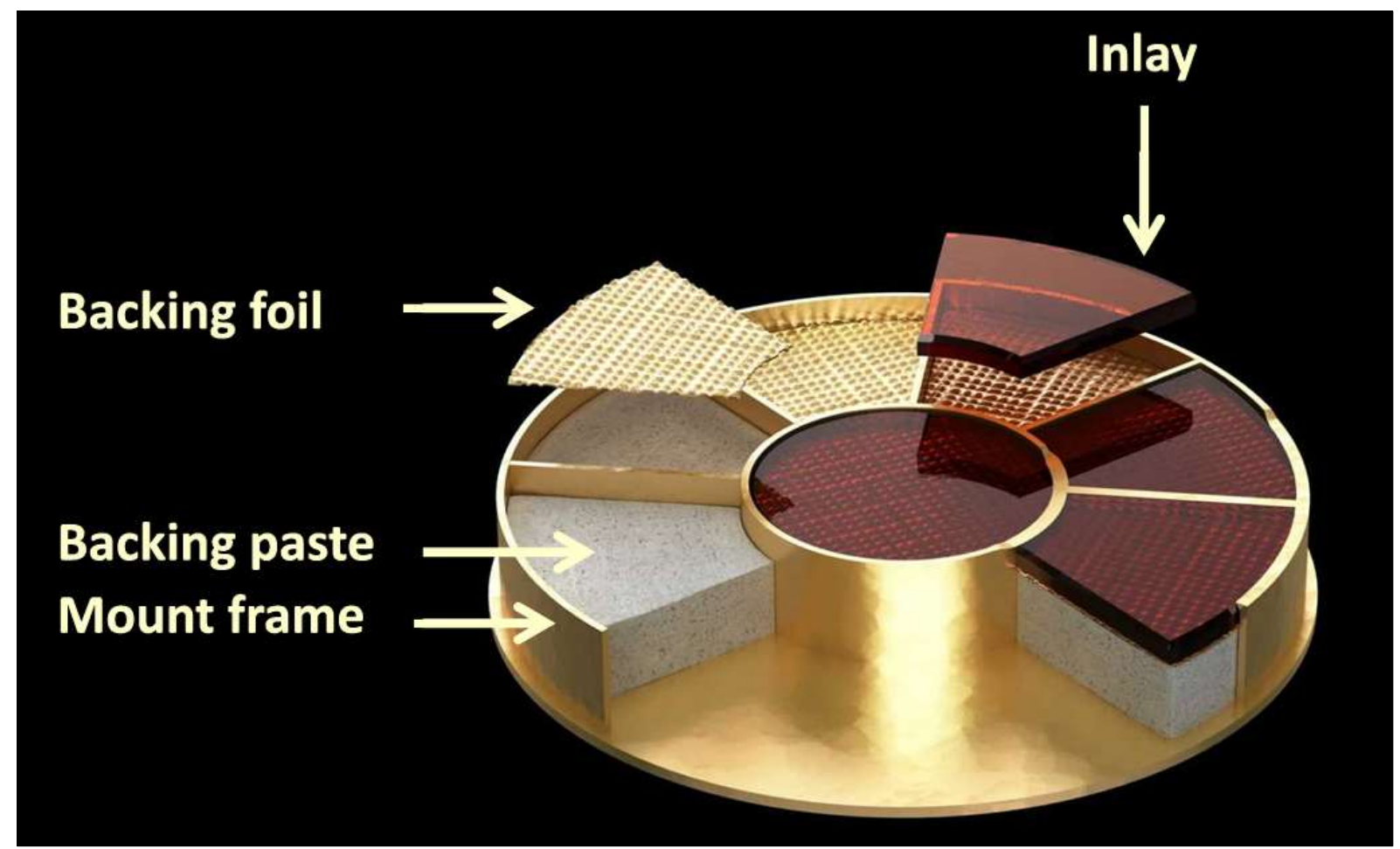

Fig. 2. Schematic construction of a polychrome goldsmiths' work (E. Horváth after GILG ET AL. 2010, fig. 2).

My classification neither related to nor overlapped the classical typological grouping, i.e. categories discerned by the typical formal marks of the artefacts. Often the smaller or larger proportion of the finds from a certain typological group is not decorated with gemstone or glass inlays, consequently is not discussed in the dissertation. Interpretation of the polychrome fine metalwork from the Carpathian Basin proved to be likewise irrelevant from only a spatial or chronological point of view, since relationships of the finds may exceed both regions and periods. Finally, I have found it necessary to discuss the production independent from ethnicity as well. Instead, as a result of the completed comparison I created more neutral categories, so called materials technological groups, which served as reliable bases for the interpretation of goldsmithing traditions, organisational background and workshop affinities. Materials technology is a collective noun that covers the relation of the raw materials, the construction as well as the manufacturing, joining and decorative techniques.

2 These fundamental features were determined by Orsolya Heinrich-Tamáska investigating damascened iron artefacts as well as silver castings ornamented with Germanic Animal Style (HEINRICH-TAMÁsKA 2005). 
Research has a special interest in tracing the origin and roots of the 5th-6th century "polychrome style". Although stylistic (formal and semiotic) as well as technological aspects have already been highlighted several times, ${ }^{3}$ the revealed differences and relationships have not been interpreted in the context of the goldsmithing traditions. Considering and reviewing the former results I have undertaken to reconstruct the process when different decorating arts have been turning into traditions. As a first step I brought the goldsmith technology into focus. Unlike the main research tendencies I did not concentrate only on the application forms of the garnets and other sorts of gemstones. In the question about the origin of the decorating art I put the most significant role on the manufacturing technology, as it reflects the roots of the handcrafts traditions best. In contrast, the choice of the various metals and minerals used have probably been stronger influenced by economic and cultural changes.

Regarding the production of polychrome fine metalwork I analysed the issue of the organisational background from two different aspects; the aspect of the raw material supply and the workshop organisation. Interpreting the archaeometric results my attention was directed to the trading and economic background of the supply as well as to the different levels of specialisation of handcrafts and the different levels of cooperation of the particular craftsmen. In view of the material composition of the artefacts I could contribute to the question of the provenance or preceding uses of the raw materials. Considering material and technological characteristics I discussed both the efficiency of the work invested in the manufacture and the standardisation of the workflow in a relative way. In the examinations I also paid attention to the general parameters of the organisation of handcraft activities, i.e. their context, concentration, scale and intensity. ${ }^{4}$

In the question of the workshop affinities I supposed that workshop practices were represented by both individual and common characteristics, related to the given craftsman or workshop and to several workshops, respectively. Revealing individual traits of workshop practice I aimed to prove or disprove the identity of the production site. On the other hand, identification of common traits having regional influence played an important role in the distinction of the production areas.

My interpretation of the individual workshop affinities was first of all based on the observation of the technical details worked out consistently, driven by automatism. Apart from this, because of the complexity of the base-material and the manufacturing technique I took into consideration certain material features as well, with higher weights. In contrast, in the attribution of the finds I attached less importance to the iconographical characteristics and the ornamental composition.

I considered the natural capabilities of the given territory as well as the economic and trading possibilities of the given population as regional determinants of the production. Furthermore, in the absence of more relevant information, I also viewed certain materials technological characteristics (know-how) to play rather a regional than an individual role. Finally, I paid attention to the ideological and social principles as well, which might generally limit the scope of the admissible formal and ornamental traits in a particular region. As I pointed out, the effect of these three factors, i.e. capabilities, knowledge and principles could not have materialised only spot-like but rather in some wider districts, determining together the characteristics of the artefacts.

3 e.g. Kendrick 1933; Zaseckaja 1999; AdAms 2000.

4 Costin 1991, 11-18. 


\section{New results}

\section{Materials technological groups}

Classifying the polychrome artefacts I considered them first as whole units represented by their form and function. In the next step I particularly dealt with three of their main structural elements: the base, the mounts and the accessory ornaments. Among all of them I paid the most attention to the characterisation of the mounts giving full particulars about features and types of the frame, the inlay, the backing paste and the backing foil and discerning their ornamental, technological and material characteristics. A set of the values of these variables defined the criteria for the comparative analysis (Fig. 3).

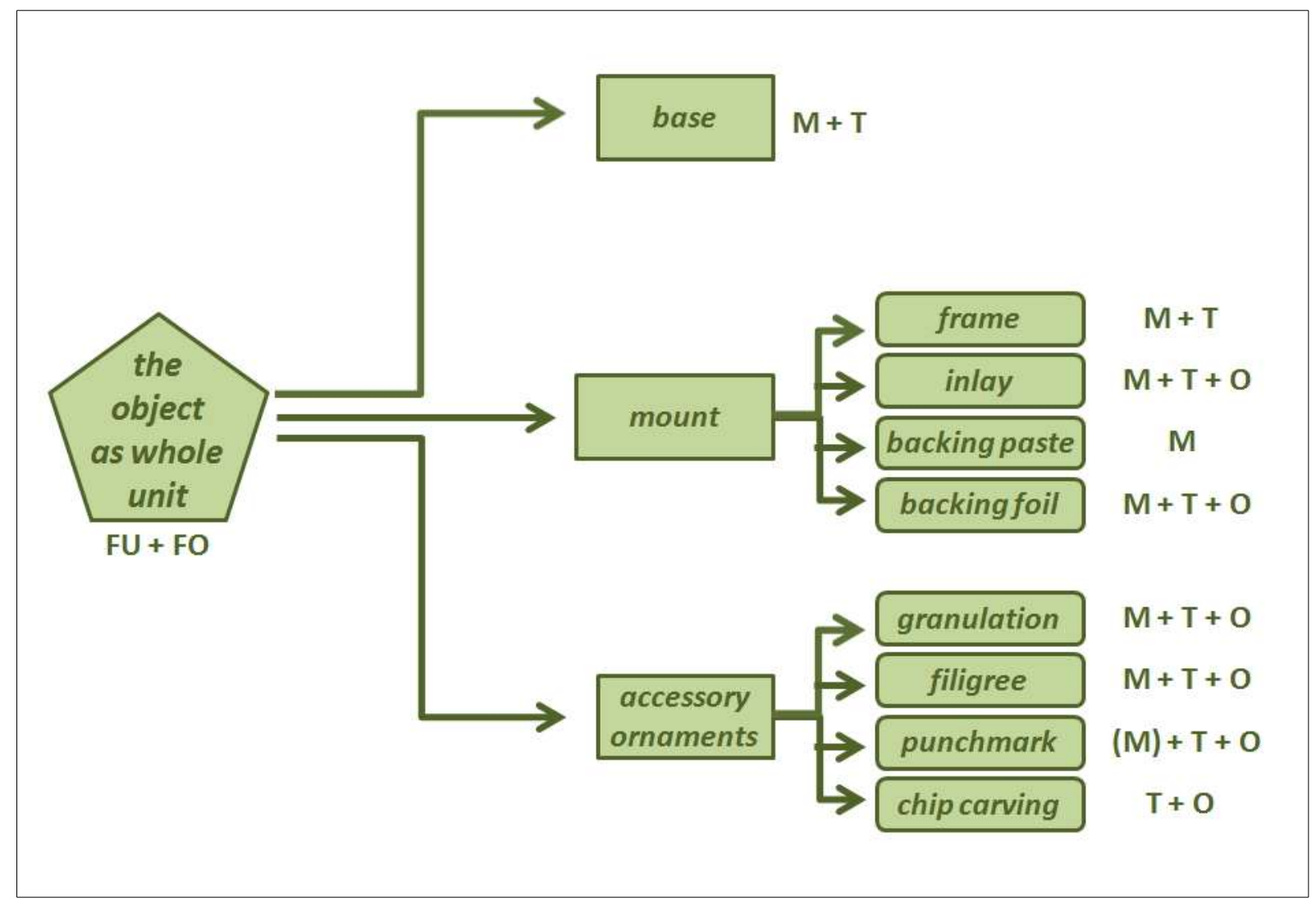

Fig. 3. Set of values that defines the criteria for the comparative analysis; FU: function; FO: form; M: material; $\mathrm{T}$ : technology; O: ornamentation (E. Horváth).

By means of optical microscope observations I could identify previously unknown technological details. These served as the basis for the revision and development of the technological classification used in the previous literature. For instance, within the art of incrustation I discerned the true and the pseudo cloisonné techniques (Fig. 4). I listed variations of this latter one among the champlevé techniques. Apart from the well-known types of mounting I detected and designated the phenomena of the suspended cloisonné (a kind of true cloisonné technique) as well as of the jointed champlevé (a kind of champlevé technique). Identification of these two technical practices not only led to refining the classification but also had great importance in the discussion about both the organisational background and the workshop affinities. 
a)

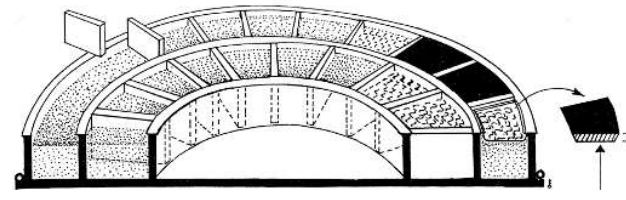

b)

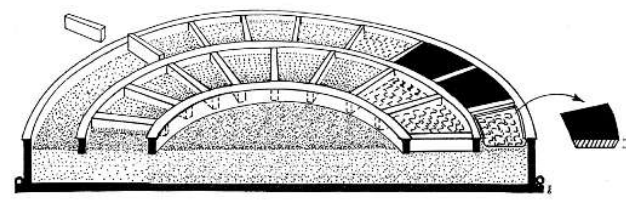

c)

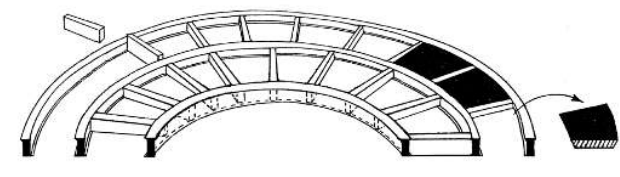

d)

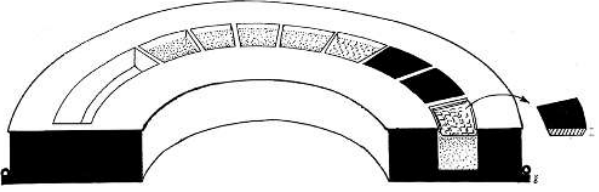

e)

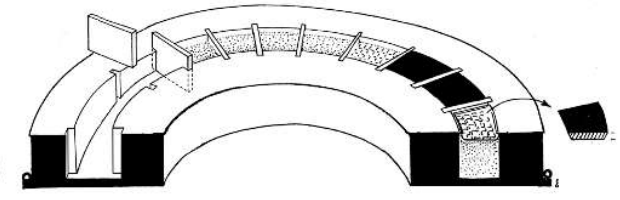

f)

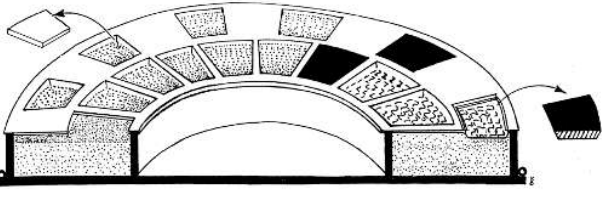

Fig. 4. Construction of the true cloisonné (a-c) and pseudo cloisonné (d-f) techniques after Honváth 2012a, Fig. 2: a, standard cloisonné; b, suspended cloisonné; c, cloisonné à jour; $\mathrm{d}$, standard champlevé; e, jointed champlevé; f, champlevé à jour.

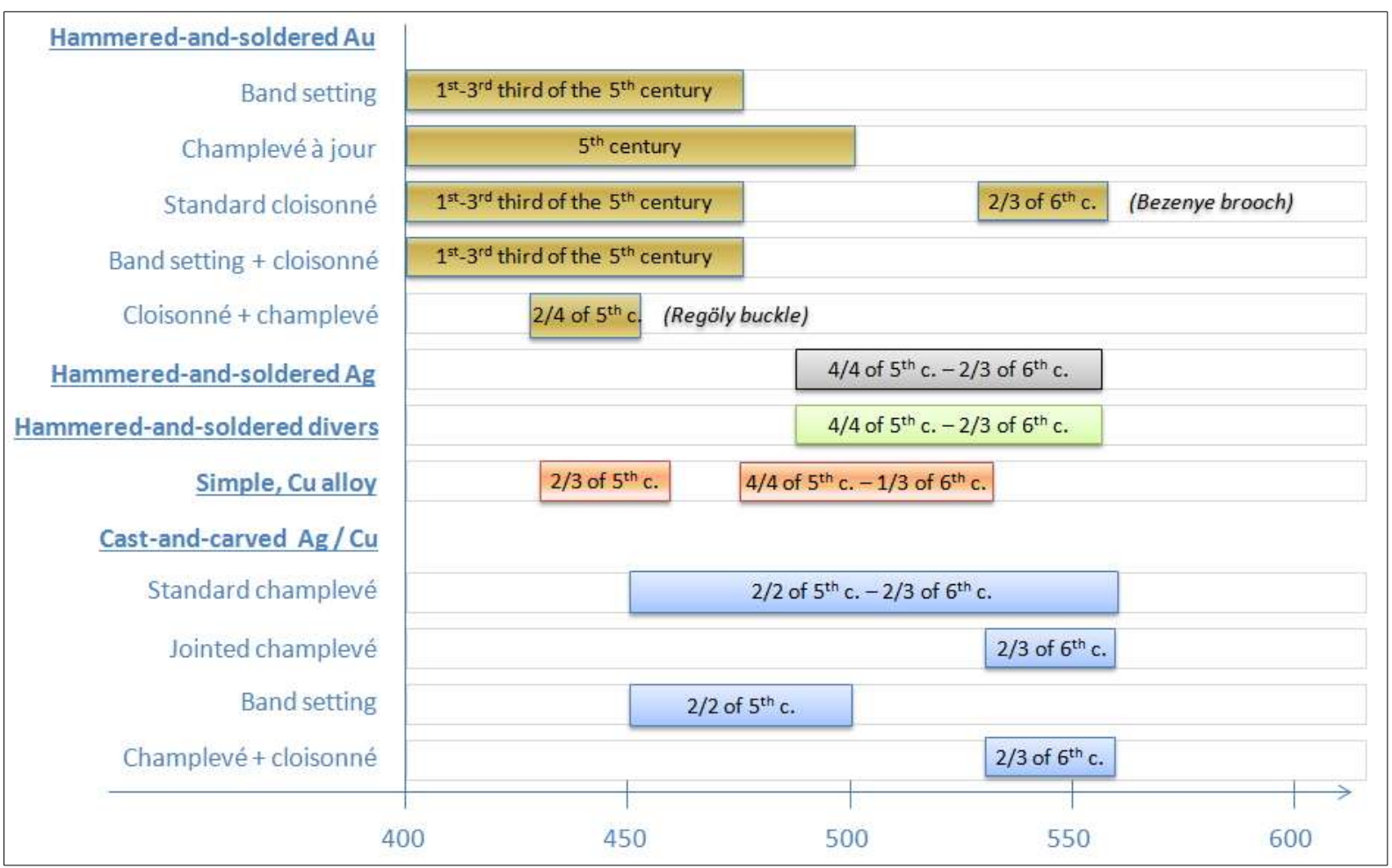

Fig. 5. Chronological relationships of the five materials technological groups (E. Horváth). 
As a result of the comprehensive analysis I have discerned five materials technological groups:

- hammered-and-soldered gold artefacts

- hammered-and-soldered silver artefacts with standard cloisonné technique

- hammered-and-soldered artefacts made of diverse base-metals with suspended cloisonné technique

- simple copper alloy artefacts

- cast-and-carved silver- and copper artefacts with champlevé technique

Based on ornamental and technological features of the cellwork-construction I have divided the first and fourth group into further variations. I interpreted the chronological and regional distribution of the analysed polychrome finds from a perspective of the materials technological groups. I outlined the chronological relationships of the five groups and their variations and presented the overlaps and hiatuses observed among them (Fig. 5). I paid special attention to the buckle from Regöly (Fig. 6). Based on its technology and ornamentation I considered it as an innovative, relatively modern work of art.
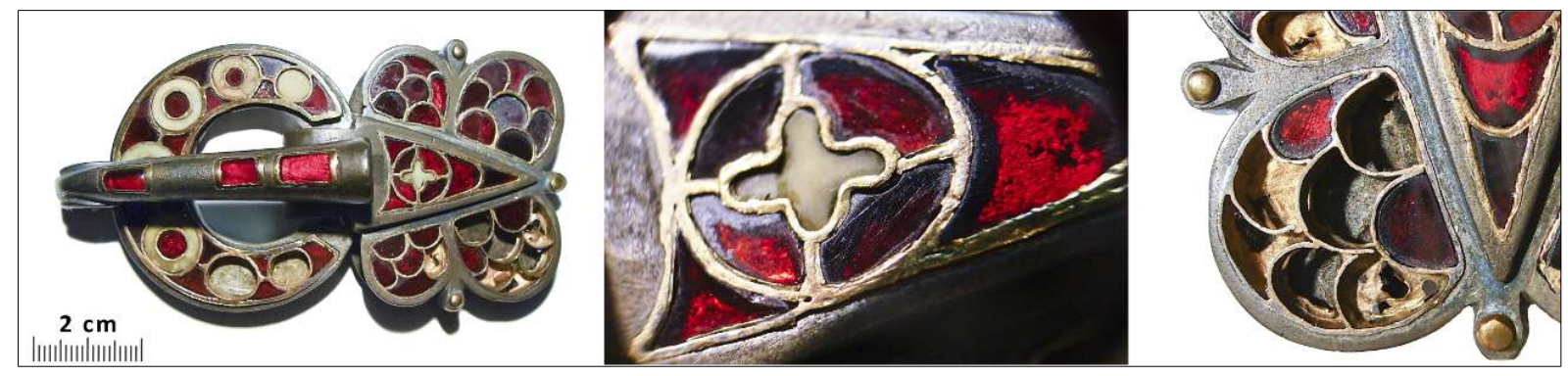

Fig. 6. The buckle from Regöly representing innovative technology and ornamentation (Photo: E. Horváth).

\section{Goldsmithing traditions}

Goldsmithing tradition with Hellenistic roots - hammered-and-soldered artefacts

Production of gemstone decorated gold artefacts have been started far earlier than the Great Migration Period. According to the existing research results the line of the direct preceding phases can be traced back until the Hellenistic Period, the 3rd-2nd century BC. At the same time we cannot disregard the distant roots of this art of incrustation in the ancient Persia and Egypt as well as the combination and hybridisation of the Imperial and Barbarian elements (Fig. 7). Consequently, I discerned the further and later examples of this hybrid style in the material of the Iberian royal tombs, barrows at the steppes, chamber graves at the Crimea and last but not least of the graves, treasures and ritual deposits in the Carpathian Basin.

Artistic influences came from several directions having strong impact to the cultural border zones. Among the centres of the Roman Empire I assigned a special role to the areas of the Crimea and the Caucasus, while the distribution of the analogous finds points out the early integration of the polychrome goldsmith art in the Mediterranean region as well (Fig. 8a). 
The further spread, changes and developments of this art were crossing not only the temporal and spatial but also the cultural boundaries. As a consequence the ancient and especially the antique ornamental elements might be identified in different forms but still as common features in the material culture of the various Barbarian peoples from the Hellenistic through the Roman until the Early Byzantine Periods.

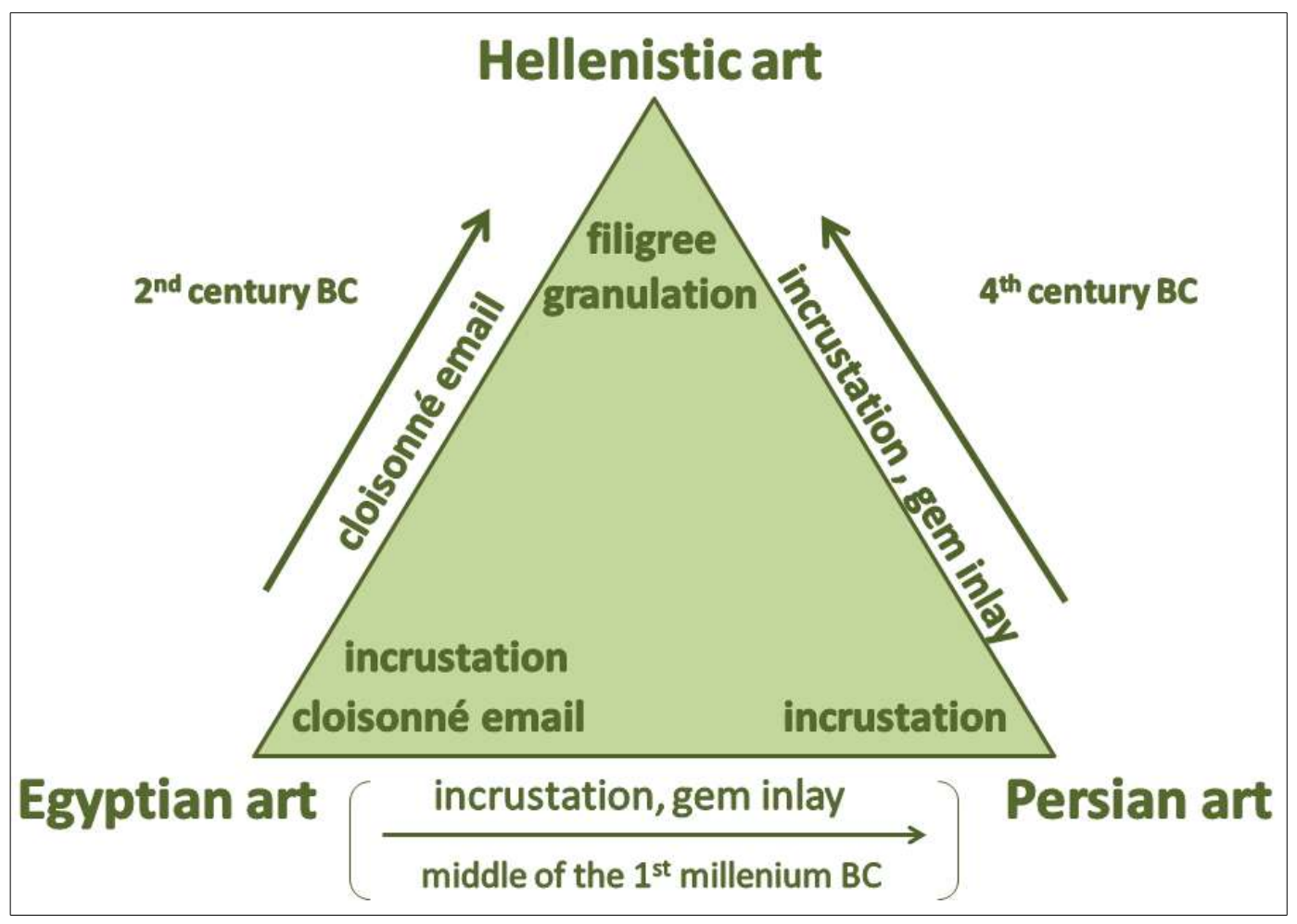

Fig. 7. The roots of the Hellenistic decorating art (E. Horváth).

As I concluded, the Hellenistic goldsmithing tradition appeared in the Carpathian Basin by the influences from the regions of the Black Sea and Mediterranean Sea. Based upon my observations, a transformation process could have been traced back related to the decorating art. Changes occurred mainly in the colours, parameters and motives of the inlays. These latter ones necessitated the improvement of the gem cutting technology and on the other hand led to more complex cellwork-constructions. I underlined that this process has been realised still before the 5th century AD. Even though I could observe significant differences in the technological quality, these variations do not follow a trend. Finds of higher or lower quality occurred inconsistently that I explained as the result of differences in the workshop practice. Precious materials used on the hammered-and-soldered gold artefacts from the Hunnic Period Carpathian Basin refer to the goldsmith activity of the central territories of the Empire.

I emphasised that in the second half or last third of the 5th century cloisonne decoration occurred only on the east side of the Danube within the Carpathian Basin. Relevant archaeological material unearthed in the neighbourhood of Kolozsvár (Cluj) implies the central role of Transylvania. ${ }^{5}$ For this phenomenon the alliance between the Gepidic Kingdom and the 
Eastern Roman Empire served as a possible explanation. ${ }^{6}$ On the other hand, Early Merovingian Age hammered-and-soldered artefacts made of silver or diverse base-metals enriched mainly the western Germanic material of the Transdanubia, i.e. the area west of the Danube. My examinations on the examples from the second and third materials technological groups pointed out that there is no local continuity of Pontic-Mediterranean influences and no resurgence of the local crafts. This cloisonné jewellery rather represents a mode and a technological transfer arrived from another direction. There is so far no argument from the 6th century Carpathian Basin that would suggest the direct continuity of the 5th century cultural phenomena. ${ }^{7}$

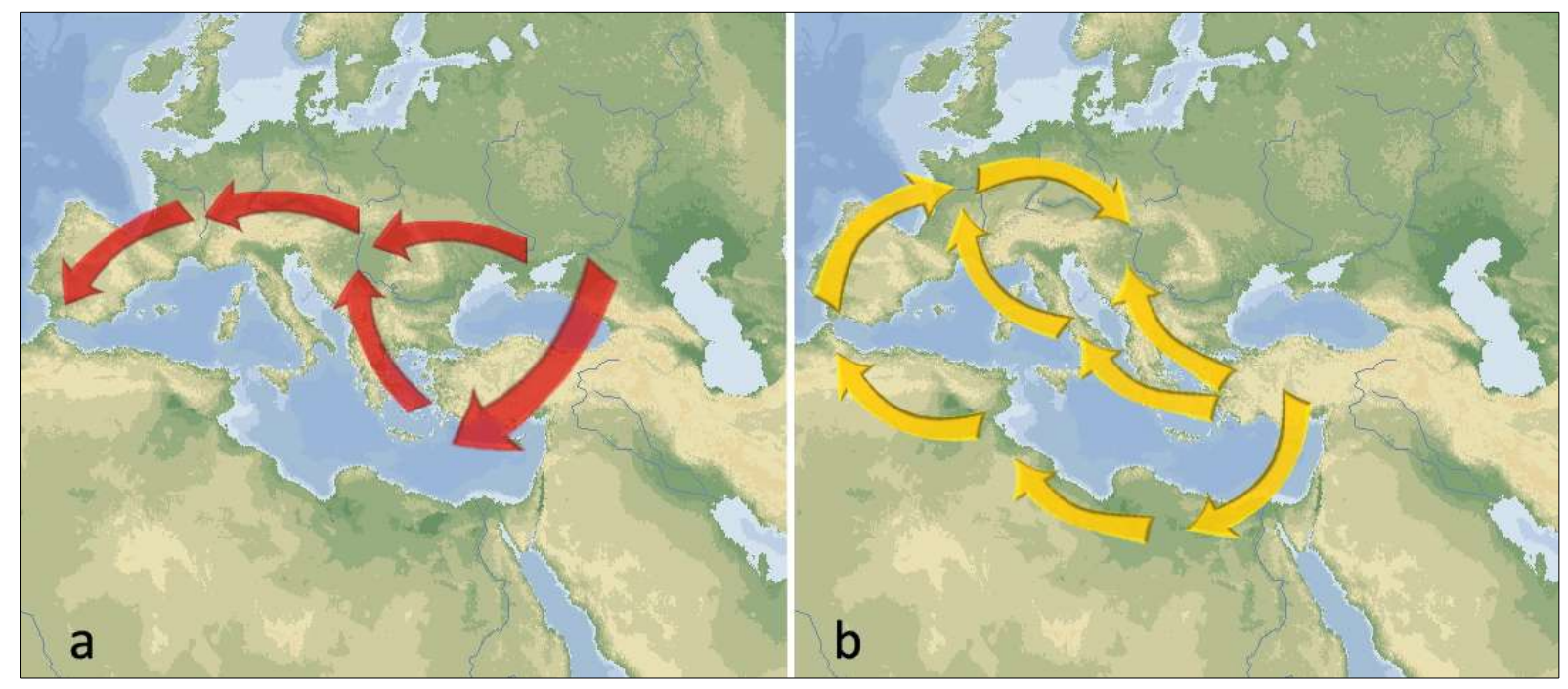

Fig. 8. Spread of the Hellenistic decorating art in the 5th-6th centuries AD (E. Horváth).

In view of the investigated finds I interpreted the late 5th and 6th century flourishing of the cloisonné art as the result of Mediterranean influence. My conclusions strengthened the theory formed by the earlier research about the western European material. This influence has arrived in the Carpathian Basin either directly or through the Merovingian territories, indirectly (Fig. 8b). Goldsmith works decorated with true cloisonné technique and made of silver or copper alloys or even diverse base-metals indicated a late antique continuity of the Hellenistic goldsmithing tradition; however, it reflects a more provincial character. This spread of the tradition has occurred simultaneously but likely independently from the changes and developments taken place in the Roman and Hunnic Period Crimea and Carpathian Basin.

\section{Goldsmithing tradition with Late Roman roots - cast-and-carved artefacts}

In comparison with the above discussed artefacts I found the production of the 5th-6th century cast-and-carved polychrome finds considerably different. Not only the applied manufacturing and decorating techniques, but even the position and role of the inlays within the composition lack the resemblance. Investigating the origin of this decorating art I assign great significance to the distribution of comparable finds from all over the 5th-7th century Barbarian territories.

6 This alliance began with the disintegration of the Hun Empire and lasted until the outbreak of the Gepidic-Langobardic wars (KIss 1991, 115-120). The most important archaeological evidences for the Eastern-Mediterranean relationship with the Germanic aristocracy are the three Gepidic royal graves from Apahida containing luxurious Byzantine goods and insignia (Horedt - Protase 1972; KaZANSKi ET AL. 2002).

7 HoRváth 2012a, 216-233. 


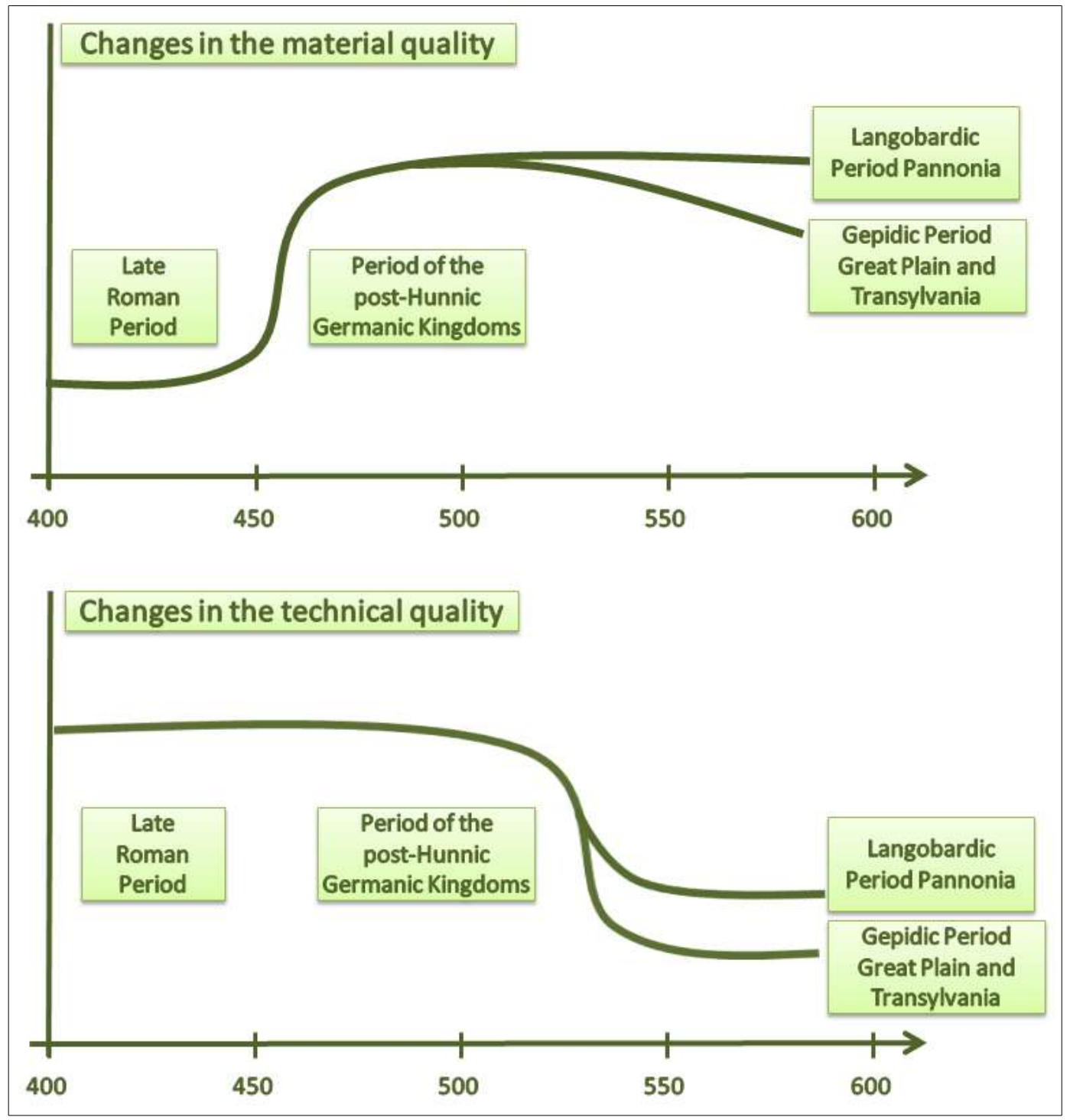

Fig. 9. Chronological changes in the material and technical quality of the cast-and-carved artefacts (E. Horváth).

Concerning the chip carved cast artefacts of the Migration Period and Early Middle Ages I discussed their antecedents following the line until the so called Kerbschnitt Bronzen - products of the Late Roman provinces along the Limes. Accepting theories of the former research I related the origin of their figural and geometrical motives to the late antique decorating art and mythology. ${ }^{8}$ In accordance with the majority of the scholars I considered the Germanic foederati and mercenaries as the link between the Roman and Barbarian world. The Kerbschnitt Bronzen and the investigated chip carved artefacts seemed to be analogous concerning the characteristics of the materials technology. As an interpretation I referred to the process when practices of the Late Roman workshops became a tradition. Consequently, I related the production of the examined cast-and-carved polychrome artefacts to the goldsmith activity of the provinces along the Limes. Besides, I was able to outline chronological and regional tendencies in the production of the archaeological material from the Transdanubia, Great Plain and Transylvania dated to a period of more than one hundred years. 
In comparison with the Late Roman analogies I observed that in spite of the stylistic relationships, the quality of their materials and techniques is different (Fig. 9). While Late Roman military equipment is mostly made of copper alloy, examples dated to the 5th-6th century are primarily silver castings. In addition, surface of these latter ones is mercury gilded and inlaid with niello. I found direct antecedents of this creative combination of silver gold - niello among the Imperial Period fine metalwork likewise produced in the provinces along the Limes. Until the late 4th and early 5th century this combination of materials and colours occurred exclusively but even sparsely in the equipment of high-ranked soldiers serving at the frontiers of the Empire. ${ }^{9}$ I pointed out that the process when practice of the provincial workshops continued and developed to a tradition resulted in the wide spread of these features. Niello was generally applied on the 5th-6th century cast-and-carved artefacts but with a different chemical composition. ${ }^{10}$ I emphasised that changes have taken place during the Barbarian expansion. Even though application of this decorating method continued, there is so far no argument that would suggest direct continuity of the former niello recipe as well. I revealed not only practical reasons but also cultural differences behind this change.

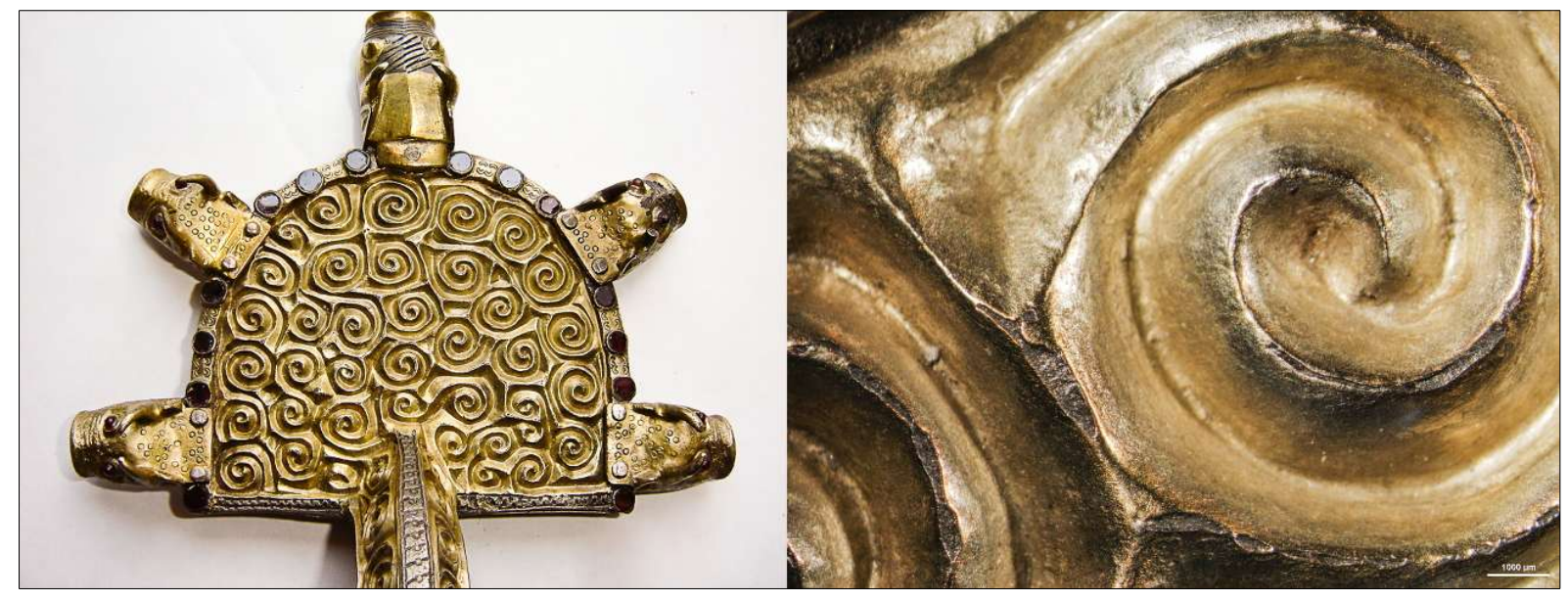

Fig. 10. Regular spiral and geometrical motives with sharp positive outlines on the brooches from Gáva implying the use of an auxiliary mould (Photo: E. Horváth).

Regarding the carved decoration I have drawn attention to the changes in the workmanship, especially in the technological quality. I observed that in the majority of the brooches, belt buckles and sword fittings dated to the second half of the 5th century (the period of the post-Hunnic Germanic Kingdoms), technical quality of the carvings still corresponds to that of the Late Roman belt garnitures. Spiral and geometrical motives are regular and have specifically sharp outlines (Fig. 10). On the other hand, this outstanding quality is not common anymore on the 6th century artefacts from the Great Plain and Transylvania, territories of the Gepidic Kingdom. I noticed a gradual decline in the workmanship of the carvings (Fig. 11). I explained this process with the lack of the elaborate and precise work and with the reduction of the workflow. My examinations pointed out that decoration of the comparable artefacts from the Langobardic Pannonia were designed in a similarly reduced workflow. However, the outlines of their carvings usually represent a higher quality than on the examples from the Gepidic territories (Fig. 12).

9 For instance the four-part belt garniture of a high-ranked Germanic soldier unearthed in the ship burial no. 2 at Fallward bei Wremen (SCHÖN 2005, 28-30).

10 La Niece 1983; Oddy ET Al. 1983; Wolters 1996; Northover - La Niece 2009. 

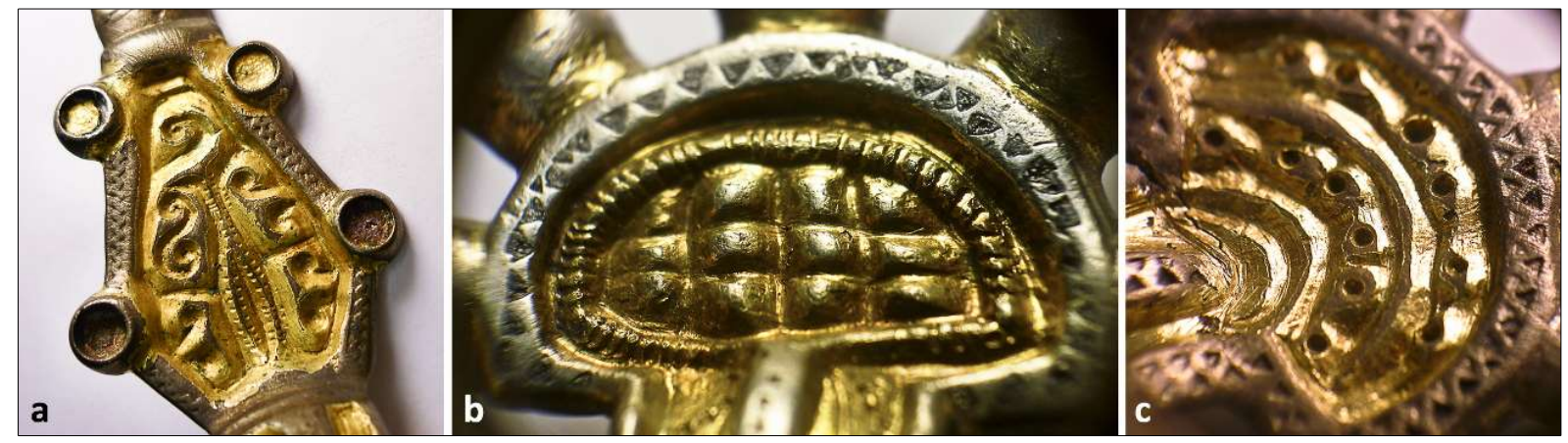

Fig. 11. Grooved and drilled ornaments designed on the wax model of the brooches from Szentes-Kökényzug: a, grave 81; b, grave 29; c, grave 7 (Photo: E. Horváth).
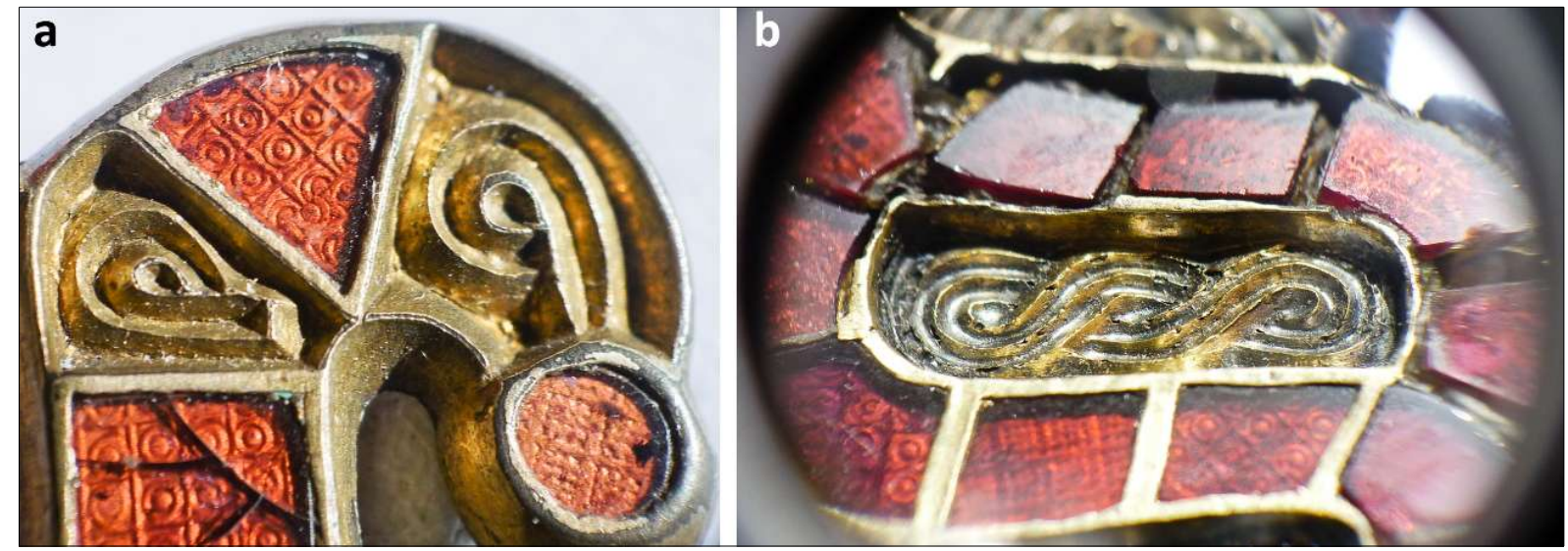

Fig. 12. Chip carved ornaments with sharp outlines on the brooches from a, Vörs, grave 33; b, Vörs grave 32.

(Photo: E. Horváth).
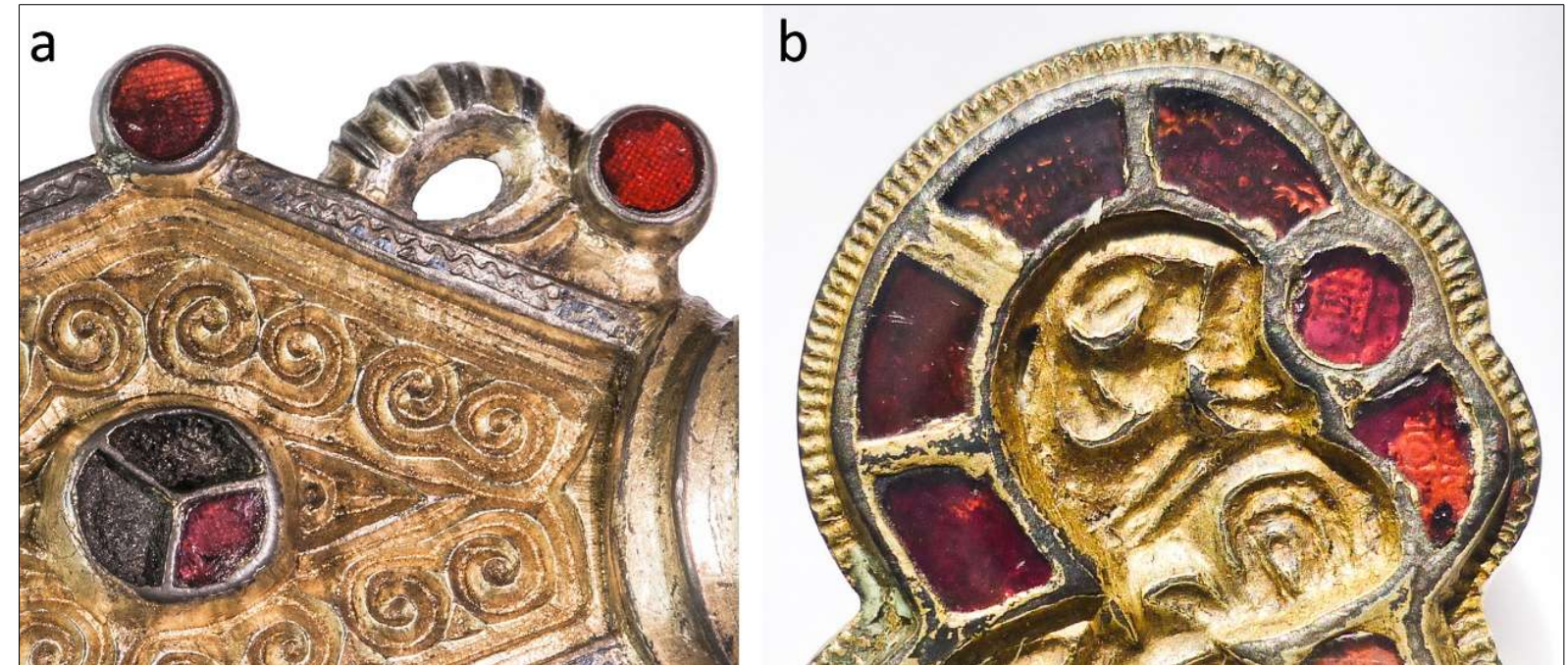

Fig. 13. Creative inlay decoration on cast-and-carved brooches: a, unknown provenience; b, Keszthely-Fenékpuszta, horreum, grave 17 (Photo. E. Horváth). 
Finally, I considered the inlay decoration as a new element on the 5th-6th century chip carved artefacts. The appearance of this grade of polychromy could be the consequence of the partially concurrent production and wearing of gemstone or glass inlaid gold artefacts, which were made according to the Hellenistic goldsmithing tradition. Even though inlay decoration is much more moderated to the 5th century gold artefacts, the feature still reflects the creativity of the goldsmiths (Fig. 13). As another improvement I considered the multi-cellwork of the 6th century cast-and-carved metalwork from the Transdanubia and Transylvania. I went into details concerning the jointed champlevé technique as well, applied on the S- and §-shape brooches in the Langobardic Pannonia. ${ }^{11} \mathrm{I}$ emphasised that this technical trick was still in practice outside of Pannonia even in the 6th-7th century; moreover, in Italy and Southern Germany it had further developments. Thus, the process when practices of the Late Roman provincial goldsmiths became a tradition did not rule out further developments and innovations.

\section{Organisational background of the production}

\section{Raw material supply}

The used raw materials provided different possibilities in the determination of the geological provenance. I discussed the natural, human (one-time population) and scholar factors playing role in the background. Concerning the metal alloy components, recyclability of the base materials as well as the corrosion and enrichment of various chemical elements at the surface of the objects raised difficulties in the provenance study. For this reason, metal analyses had significance primarily in revealing the sort of preceding use and application phase(s).

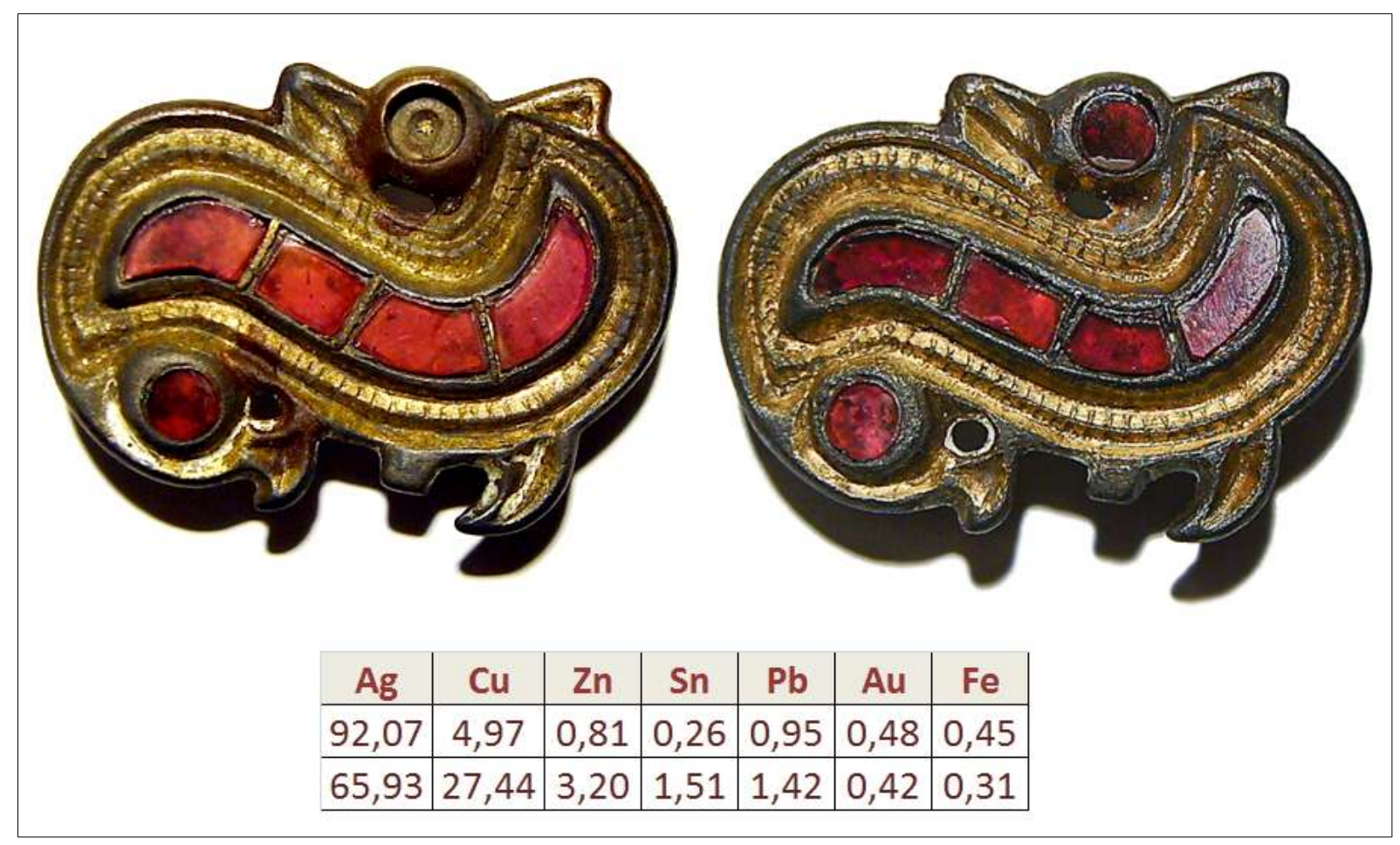

Fig. 14. The pair of brooches from Kajdacs, grave 52 made of two silver alloys with different elemental composition. (XRF data on the silver background, in weight \%. Photo: E. Horváth).

11 HoRvÁth 2012a, 216, 225-232. 
Based on the different quality of the base-metals I discerned several groups of gold, silver and copper alloys. Considering their technological characteristics I pointed out that the majority of the groups does not reflect any typical alloying practice. I named only a few examples of silver and copper alloys as exceptions: in the selection of their components I supposed awareness or the effect of standardisation. According to my observations, quality of the base-metals did not depend on the practical aspects but usually on the financial circumstances, on the demand of the customer as well as on the available stock of gold, silver or copper. I based my conclusions on the differences showed in the base-metal composition of those artefacts, which were produced as a set of jewellery at around the same time and in the same workshop (Fig. 14). I highlighted some extreme examples as well where the material composition and the workmanship of the artefacts implied the recycling of several different objects (Fig. 15).

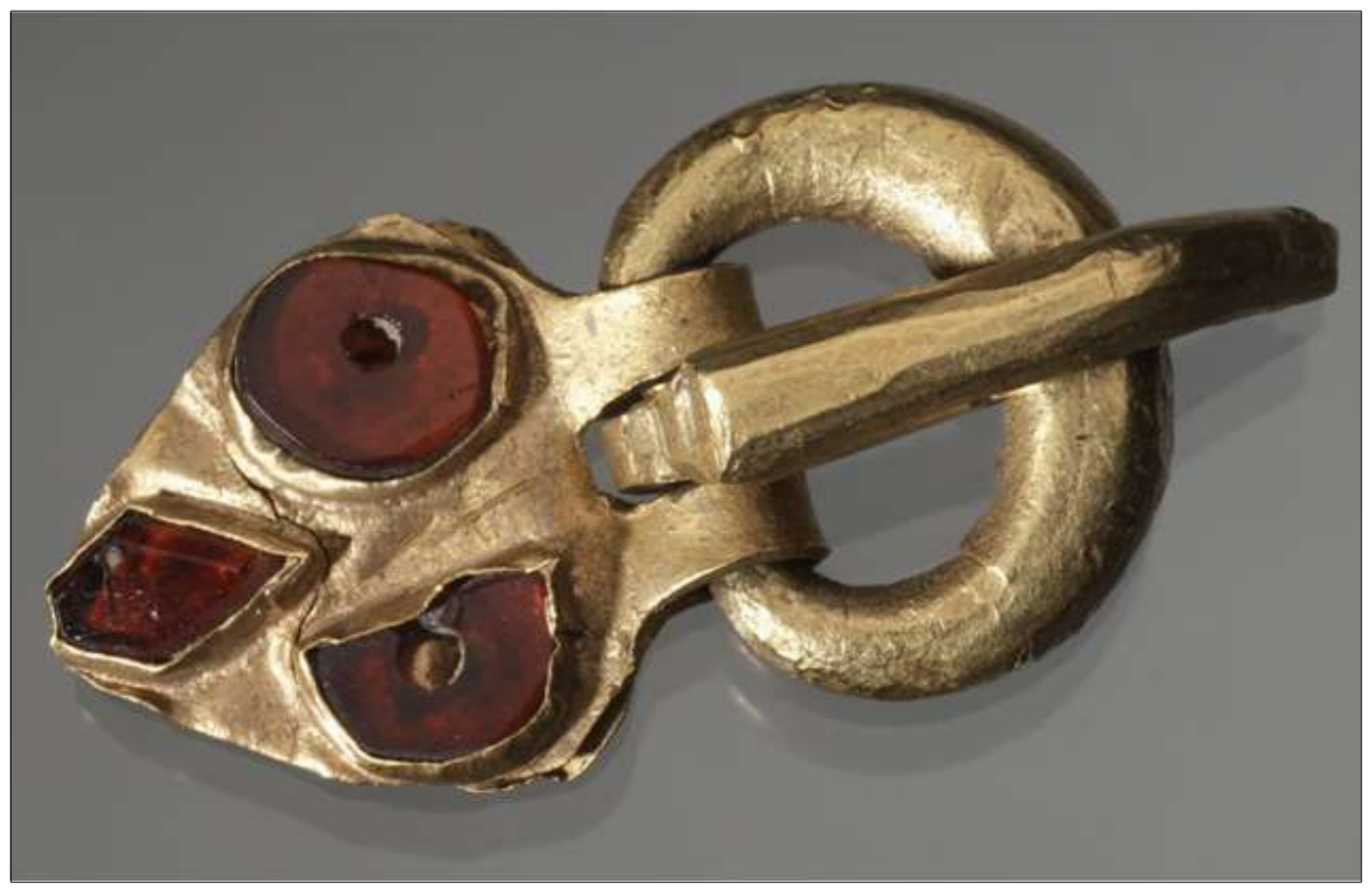

Fig. 15. Gold buckle from the Carpathian Basin made by recycling of several different objects. Plate: $\mathrm{Au} 99 \%, \mathrm{Ag}$ 0.7\%, Cu 0.2\%; Tongue: Au 85\%, Ag 14\%, Cu 1.1\%; Loop: Au 91\%, Ag 8.1\%, Cu 1.2\% (CRADDOCK ET AL. 2010, table 1; Photo: (C) Trustees of the British Museum).

Reconstructing the preceding phases of the base-metals I considered the general high purity of the gold artefacts as a significant feature. Great majority of them contains more than $93 \%$ gold but a ratio over $99 \%$ also occurs (Fig. 16). Since the not-alloyed gold is too soft and possesses low tensile strength it was practically disadvantageous for the goldsmith. I discussed the form in which this kind of good quality base material could have been available in larger quantity in the Hunnic Period Carpathian Basin. Elite of the society - acquiring Roman tributum - supposedly had their jewellery and wearing elements made of solidi by the goldsmiths of the area. ${ }^{12}$ They could also pay for the finished products with these coins.

12 Interpreting some comparative studies on Migration Period gold jewellery and coins, it was first supposed by scholars from Great Britain and Scandinavia that the source of gold might be available for the goldsmith in form of coins, solidi (Kent 1972; Arrhenius 1977; Hawkes 1984; Oddy - Meyer 1986). 
Analysed silver objects represented a wide spectrum of the material quality. In their case I have undertaken to outline a tendency. Pieces of the best quality contain $95-97 \%$ silver in accordance with the fineness of the Roman chased silver artefacts. ${ }^{13}$ I drew attention to the possibility that even finished products could serve as very good quality silver in the goldsmith workshops of the Barbarian territories. My observations implied that the products of the previous Roman workshops could play an important role in the production of various silver elements of the polychrome artefacts. Regarding the 5th-6th century, I could show a downward trend in the silver content that can be interpreted as the result of the multiple recycling. In this circulation the valuable silver - originally purified by a long process - gradually disappeared, i.e. merged indiscernibly into the various alloys.

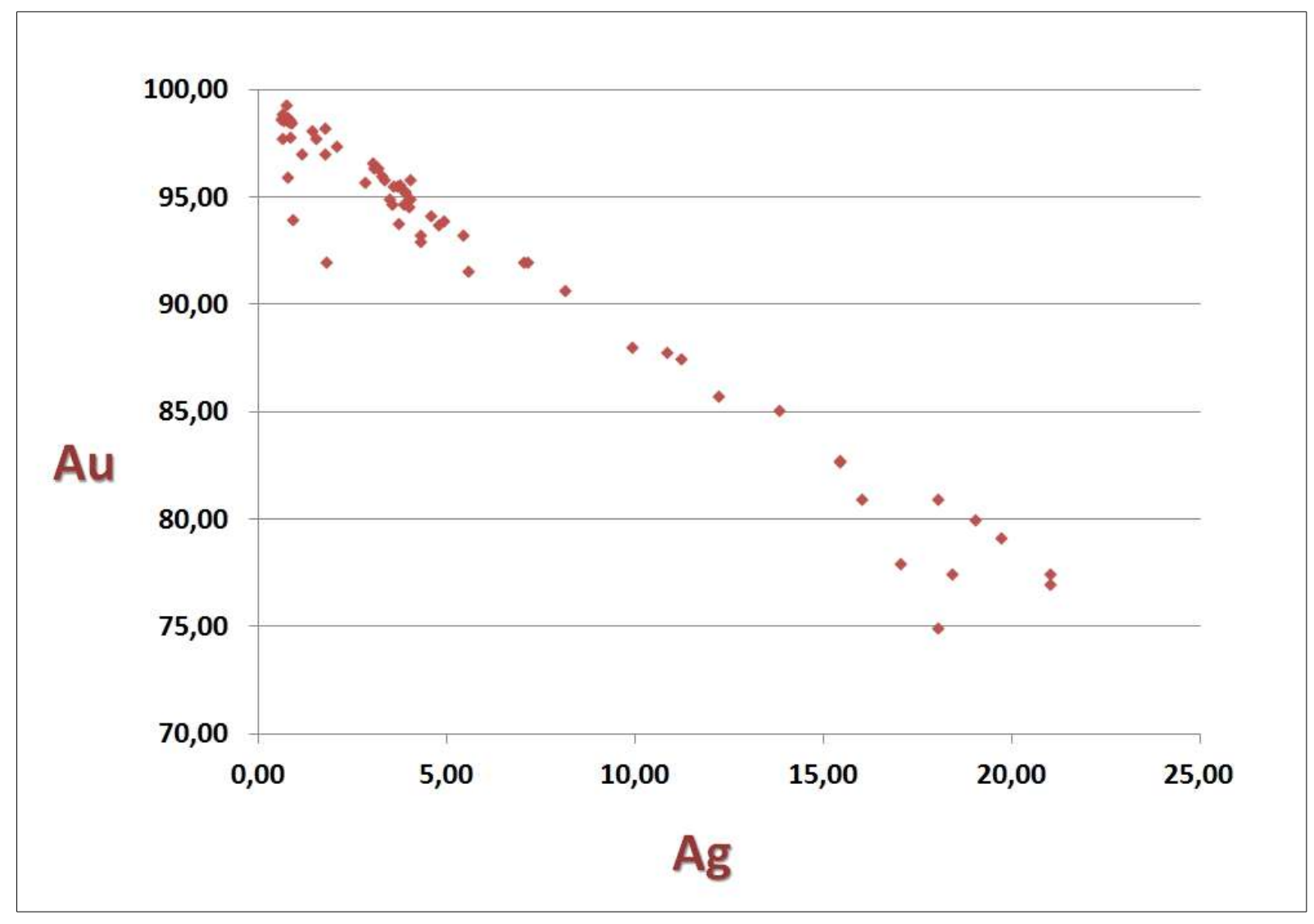

Fig. 16. Au/Ag plot representing the high purity of the investigated gold artefacts, based on XRF and SEM data, weight \% (E. Horváth).

By means of the scientific analyses material of the various copper alloy artefacts could be differentiated as unalloyed copper, bronze, brass or red-alloy. The majority of the so called Mediterranean buckles showed awareness in the use of metals. I remarked that metal composition of the brass alloys approximates or is in accordance with related data of the brooches generally extended in the Roman Period. I named two possible reasons behind this. Either the alloy was made following the Roman standard, or the goldsmith recycled some artefacts made by this standard..$^{14}$ I drew attention to the regional factors that might drive their production and to the foreign workshop practice they reflected.

13 For instance a set of sword mounts from Komárom (Komárno), now in the British Museum (CRADDOcK ET AL. 2010, table 2, reg. no. 1987,0308).

14 Based on a series of analytical results Joseph Riederer has been pointed out that the composition of copper alloys were standardised in the Roman Period, among others in the production of brass brooches (RIEDERER 2002). 
I could increase our knowledge with relevant results concerning garnet inlays of the discussed fine metalwork. Purpose of my investigation was to identify not only the mineral species but also the possible geological-geographical sources of the raw material. Due to the performed analyses Carpathian Basin is not remaining a white spot any more in the welldisputed provenance issue about the mineral raw material of the Migration Period and Early Middle Ages garnet jewellery. Examinations revealed that the investigated gemstones represent two different types of almandine as well as intermediate varieties between pyrope and almandine, moreover, in one single case andradite. In view of the former results I could clearly exclude the European sources from the group of the potential provenances of the analysed almandine and pyrope-almandine inlays. On the basis of the data available in the geochemical literature I concluded that almandine garnets with higher chromium content are nearly related to garnets exploited in Southern India, while Sri Lanka is the potential provenance of the intermediate varieties between pyrope and almandine. Regarding almandine garnets with poor chromium content I named Northern India as the possible source (Fig. 17). Last but not least, in case of the only piece of andradite I proposed the same provenance as for the intermediate varieties; even though, in absence of reference database I could not rule out Carpathian Basin from the list of the potential sources.

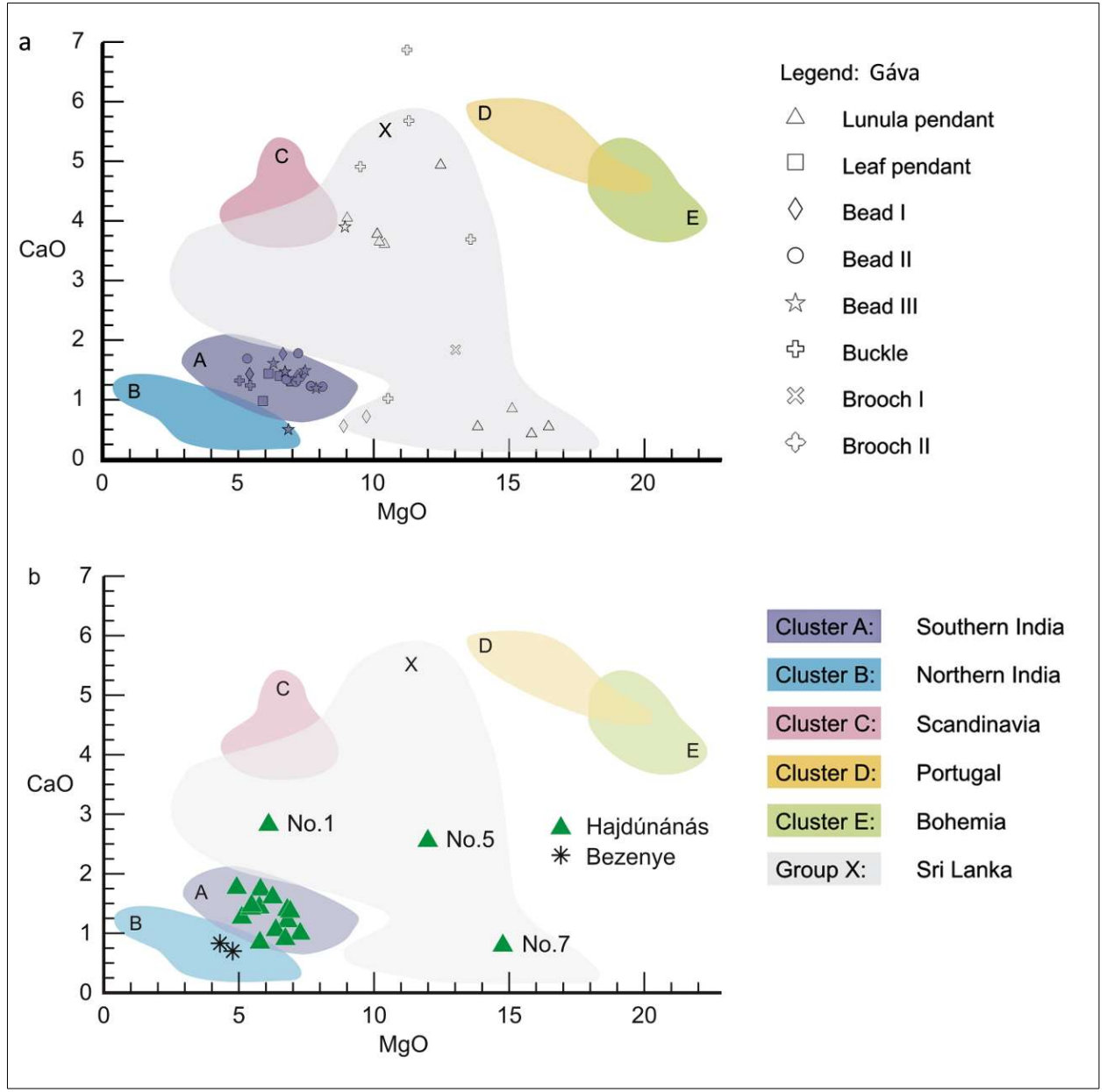

Fig. 17. Results of the geochemical analyses (SEM-EDS) of garnet composition related to the assemblages from Gáva (a), Hajdúnánás and Bezenye (b). After Horváth 2008; Horváth 2010; Horváth - Bendő 2011; Horváth et Al. 2013. The classification of possible provenances is based on Calligaro et AL. 2008, modified by GILG ET AL. 2010 (Zs. Bendő). 
Analytical results pointed out that almandine and pyrope-almandine inlays from the Carpathian Basin do not show any differences to the western territories of the continent. This correspondence indicates that this region was the part of the same trade networks. I based the clarification of the trade links reviewing results of the previous research about relevant historical sources and archaeological finds. ${ }^{15}$ Gemstones arriving most likely from India and Sri Lanka could have got to various regions of Europe - among others to the Carpathian Basin - trough sea and land routes of the long distance trade.

Archaeometric analyses, however, pointed out that the chronological order of the various garnet types used in the Carpathian Basin does not fit entirely into the typochronology outlined based on the intensively investigated find material of the western territories. ${ }^{16} \mathrm{Just}$ as it was shown in case of Western Europe, my observations revealed an accord in the supply of the particular garnet types used in the 5th century Carpathian Basin. In contrast, almandines originating from the new source of Northern India appeared in the 6th century only on artefacts of the Transdanubian region. Thus, population settled on the left coast of the Danube did not cease the use of Southern Indian and Sri Lankan garnets, which they acquired probably in the same way as before. As reasons behind this difference I found dissimilar cultural relationships as well as distinct technological characteristics of the polychrome jewellery. ${ }^{17}$

These results led to the conclusion that precious metals, i.e. base-metals of 5th-6th century polychrome fine metalwork were mostly not obtained from primary geological sites. Tribute coming from the Roman Empire as well as one-time trade wares could have served as the most reliable sources of the almost pure gold and silver material. The use of the primary sources still cannot be ruled out but analytical evidence is needed to prove this possibility. Regarding the tendency of material quality changes, I considered multiple recycling as a characteristic of the region. I supposed the standardised process of the casting in case of only one group of the copper alloys. Since their production required base-alloys of known composition, i.e. mainly purified metals, the primary raw material sources were of great significance. Concerning the applied inlay material I stated as a conclusion that at the early stage, diverse ethnical groups - settled in the Carpathian Basin - obtained garnet material from the same geological sites as people of the Frankish and Alemannic Kingdoms. However, with regard to chronological tendencies I pointed out that the practice in the area of east of the Danube did not follow entirely the changes took place in Western Europe.

\section{Workshop organisation}

First question arising about the specialisation was how many sort of handcrafts' activity can be related to the production of the artefacts. Based on the different kinds of raw material I discerned craftsmen responsible for gem-processing and metal-working respectively. At the same time I did not considered the specialisation between these crafts as a rigid framework. My observations showed that certain overlap characterised the scope of tasks accomplished by the gem-cutter and goldsmith. As an example I mentioned those garnet inlays that although

15 Historical and archaeological sources about the ancient trade between the Roman Empire and India have been recently discussed by Székely 2008. The 11th book of Christian Topography, a source contemporary with the discussed metalwork, provides valuable data about the gem trade, interpreted latest by Rотн 1980, 318-320.

16 Related to the typochronological classification of the various garnets used in the Early Medieval Europe see: QUAST Schüssler 2000, 87-90; Calligaro et AL. 2008, 128; Gilg Et AL. 2010, 94-96.

17 Horváth - Bendő 2011, 30. 
bear marks of the preparation work of the gem-cutter, might have got their final form in hands of the goldsmith responsible for the mounting (Fig. 18).${ }^{18}$ Related to the specialisation within one craft I concluded that there was not any fixed scope of tasks within neither the goldsmiths' nor the gem-cutters' activities. Craftsmen possessed extensive knowledge about various workflows differing from each other.
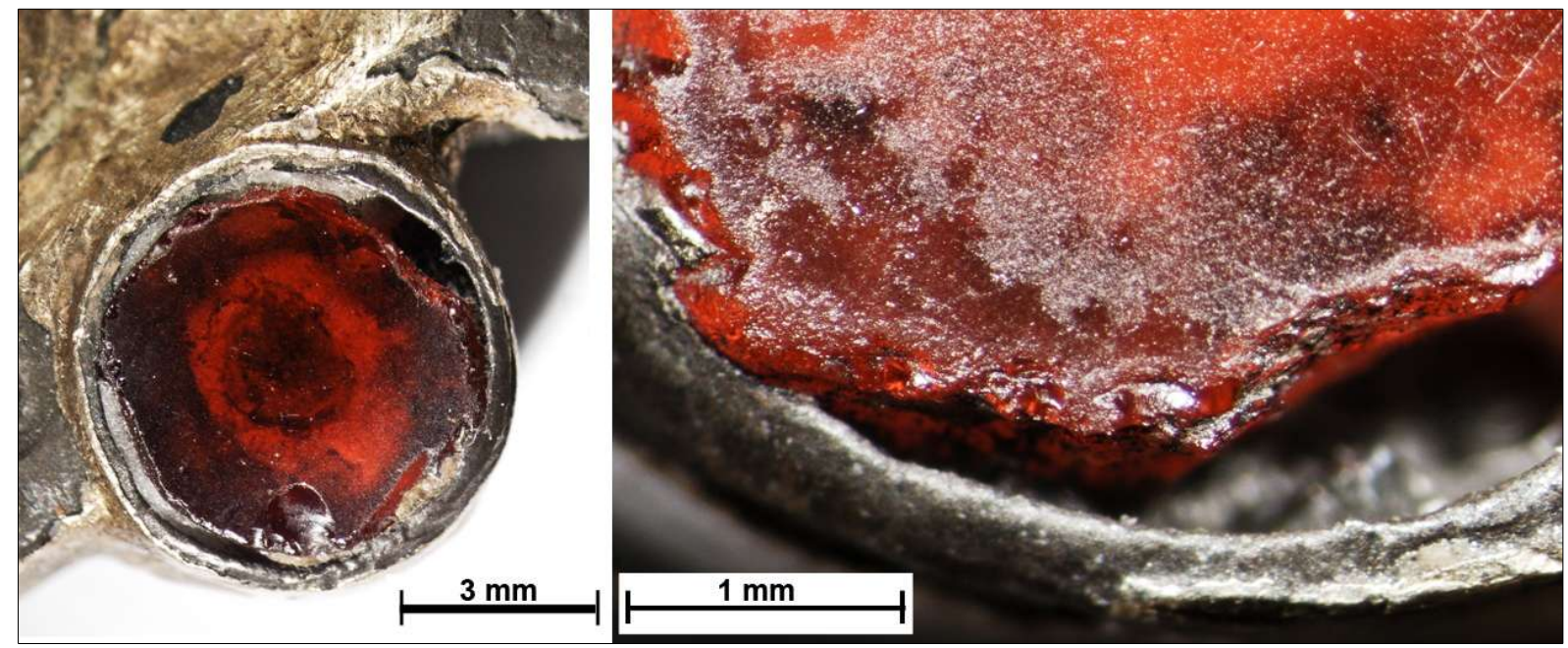

Fig. 18. Irregular round garnet on the buckle from Gáva with cut and polished surface; shaped by grooving and breaking (Photo: E. Horváth).

I related the presence or the absence of the cooperation between the specialised crafts to the degree of standardisation of the manufacturing process as well as to the individual or common features of the finished products. In one part of the investigated artefacts I could clearly verify the aligned activity of the gem-cutter and the goldsmith and I remarked also when the ornamental composition was known by both of them. As prime evidence I considered those inlays of unique form, which were mounted like elements of a picture puzzle (Fig. 6). Cooperation between the crafts allowed to create much more complex, even mosaiclike compositions that I considered as the first step to the so called engzellig ornamentation. In the other part of the investigated artefacts I could obviously exclude even the occasional cooperation. Gem-cutter could shape the great majority of the gemstone inlays even without the knowing parameters of the given goldsmith artefacts. I identified the absence of the relationship between the crafts in three different cases; when artefacts contain (1) standardised inlays, compatible in many ways (Fig. 19), (2) inlays obtained in semi-finished phase and finished likely by the goldsmith (Fig. 20), (3) secondarily used inlays (Fig. 21). In case of the standardised inlays I supposed that the goldsmith chose the needed pieces from a set or collection and shaped the settings according to their shape.

I deduced the presence of the cooperation within one single craft, i.e. the division of labour, discerning special technical marks. While these marks are related to the same phase of the manufacturing process, they represent very different quality of workmanship. As a result of the technological observation of the discussed artefacts I concluded that technical quality of the workmanship was in accordance with the designed form and ornamentation at almost every exemplar. 

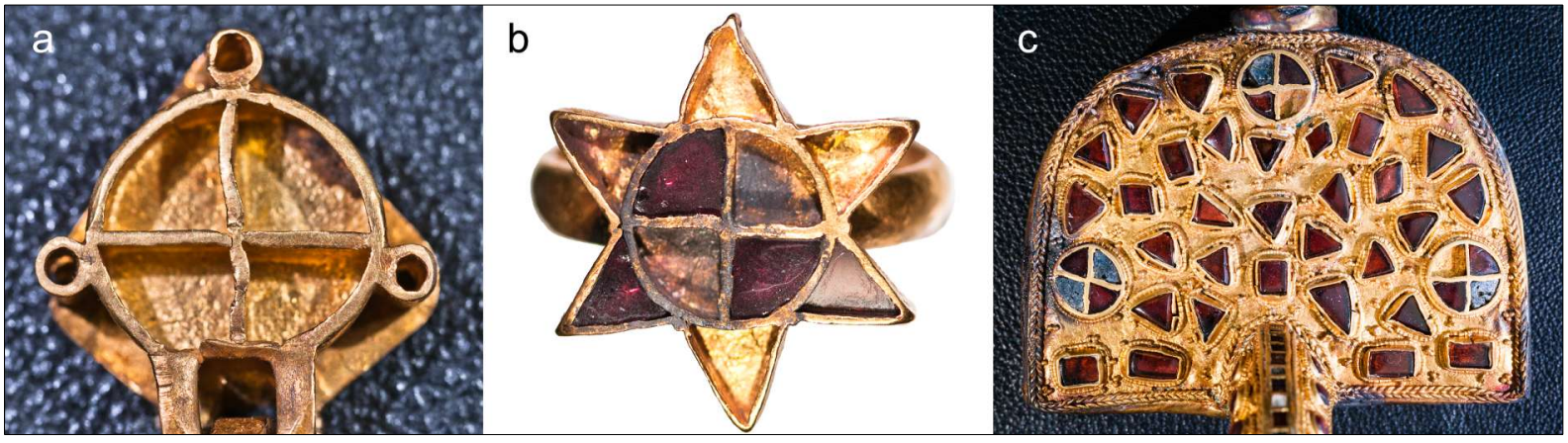

Fig. 19. Standardised inlays, compatible in many ways on a buckle from Marcelháza/Marcelová (a); a ring from Bakodpuszta (b); and a brooch from Szilágysomlyó/Şimleu Silvaniei (c) (Photo: E. Horváth).
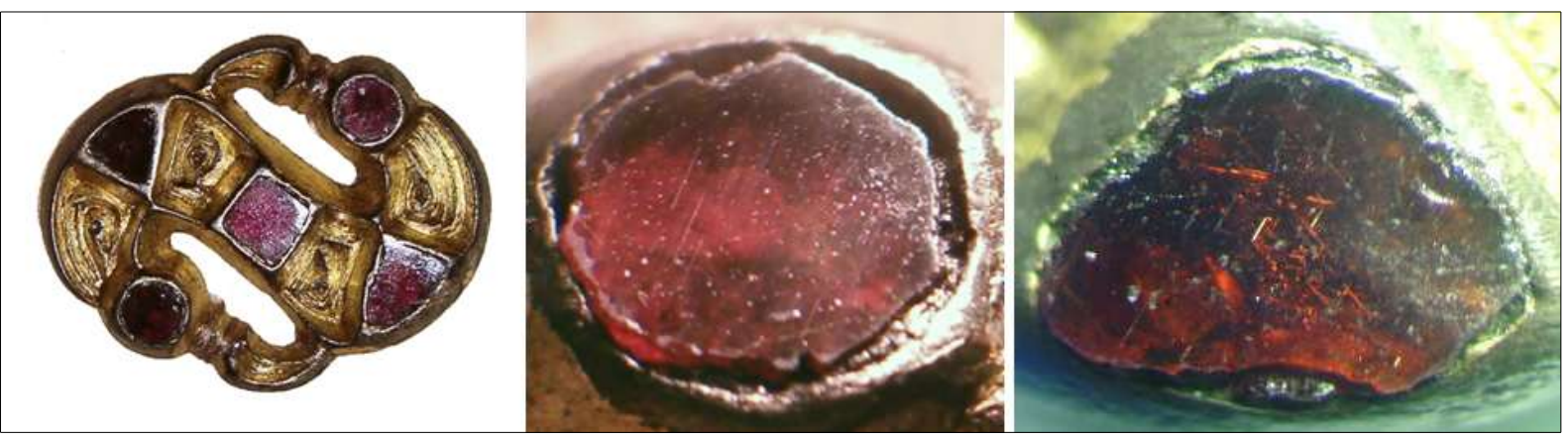

Fig. 20. Garnet inlays obtained in semi-finished phase and finished likely by the goldsmith; Várpalota, grave 19 (Photo: E. Horváth).
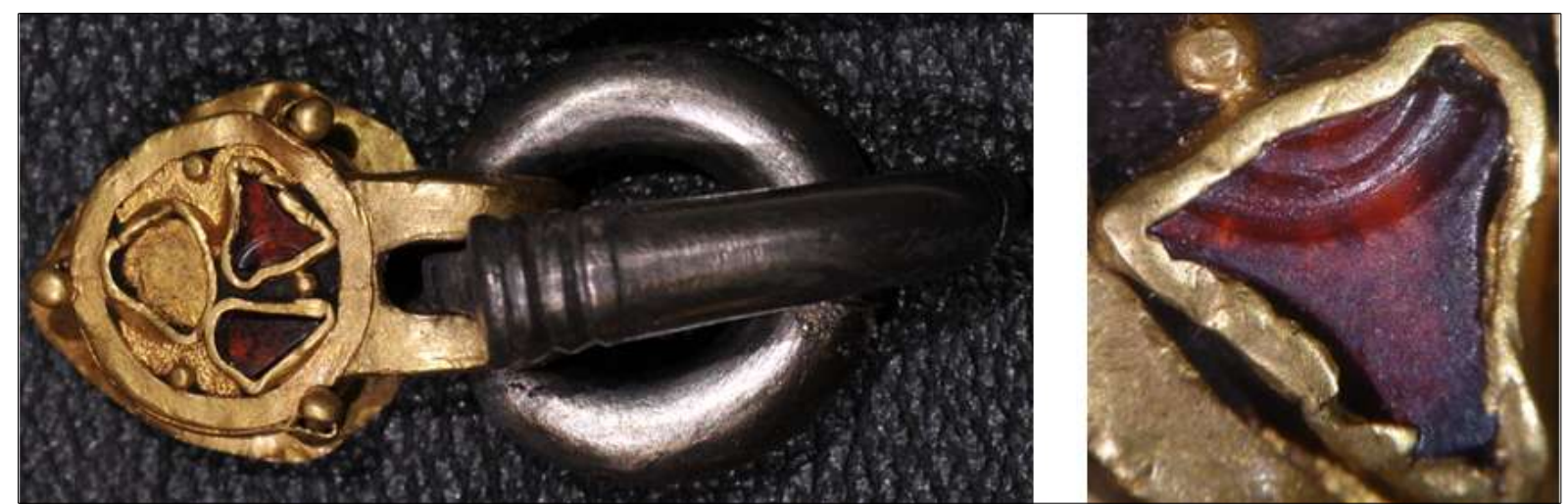

Fig. 21. Secondarily used inlays on a low quality buckle of unknown provenience in the Carpathian Basin (Photo: E. Horváth). 
If awareness and elaboration appeared in the ornamental composition, also the particular ornaments were characterised by thorough, meticulous workmanship. Similarly, poor composition appeared usually together with rough-and-ready details and careless or imperfect technical solutions. The revealed accord in the quality of the design and the workmanship implied that craftsmen consequently applied their knowledge and skills.
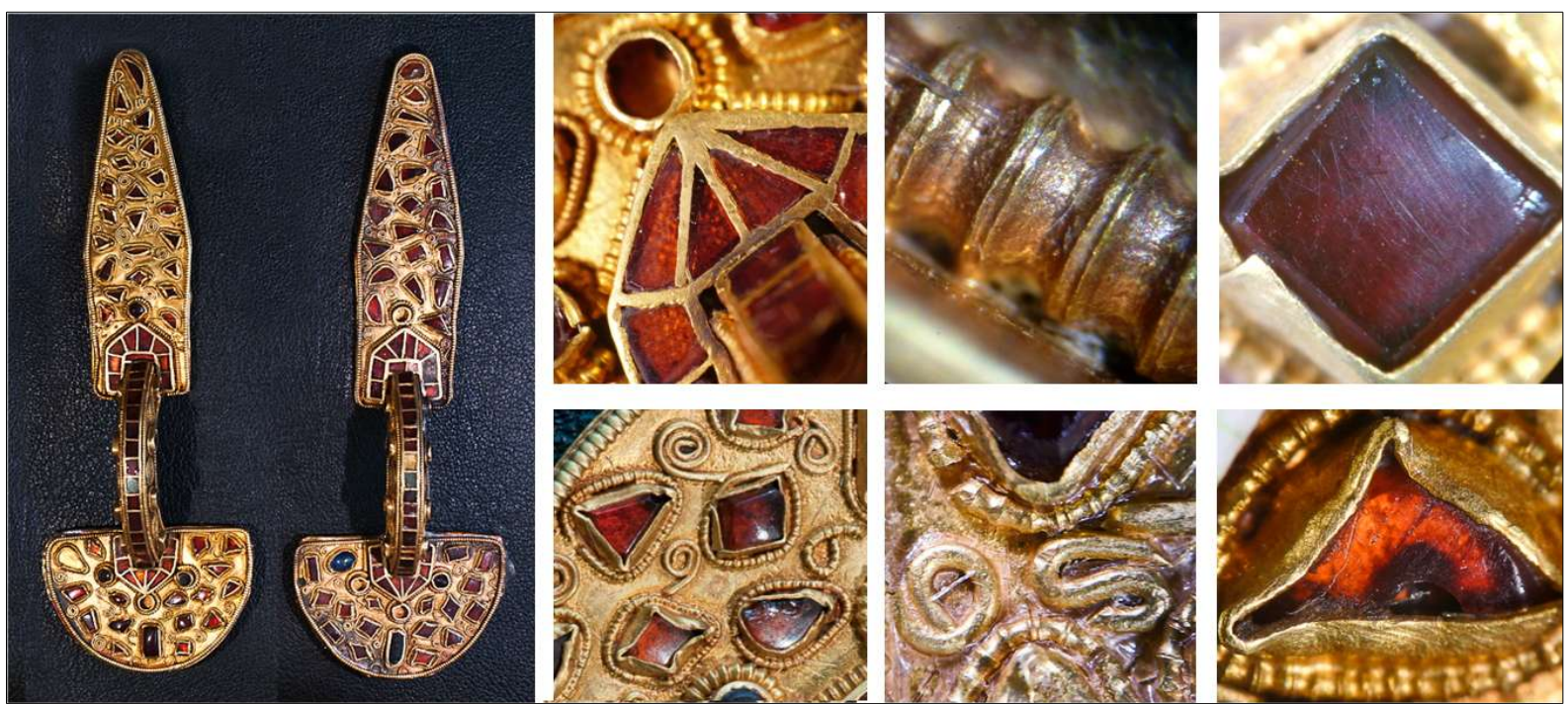

Fig. 22. Spiral decorated brooches from Szilágysomlyó (Şimleu Silvaniei) with essential differences in the workmanship of the particular phases of the workflow (Photo: E. Horváth).

I considered the pairs of the spiral decorated brooches from the Szilágysomlyó (Şimleu Silvaniei) treasure as the only exception. In case of the spiral decorated brooches I discerned essential differences in the workmanship of the particular phases of the workflow. Even though wire decorations of the brooches usually represent perfect technical details, the product itself seems to be the result of a low quality work (Fig. 22). Formerly this pair was interpreted as the imitation of a brooch produced in a high quality workshop, even e.g. one of the other brooches from the treasure. ${ }^{19}$ However, the workmanship of certain elements attesting to intensive and continuous concentration raises the possibility that several (likely two) goldsmiths participated in the production of this pair of brooches. According to my observations, one of them was responsible for preparing the ornaments while the other one for composing and fastening them. This latter goldsmith, who finished the artefact, lacked both artistic ability and patience, concentration needed during designing and fastening the elements, respectively. He simply slubbered over his work.

\section{Workshop affinities}

Another important question discussed in my doctoral thesis is whether the similarities and differences observed in the characteristics of the artefacts play an important role in the reconstruction of either the specific practices or the regional relations of the workshops. In or der to identify workshop affinities as well as to discern their possible degree, a set of criteria were developed based on the typical features of the production. I highlighted four groups of traits as criteria: (1) specific construction of the finds, (2) specific tool-marks, (3) composition of the receipt-like elements, (4) technical workmanship (quality and unique marks) of 
the different phases of the workflow. In addition, I have drawn attention to the typical combinations of the particular characteristics as well.

In case of the hammered-and-soldered gold artefacts, specific or unique elements of the construction as well as particular joining and fastening practices proved to be fundamental. Furthermore I labelled specific tool-marks and quality differences - manifesting in some manufacturing phases, such as the production of the backing foils, punchmarks, filigree work and pressed borders - as essential indicators. Among the receipt-like elements I highlighted the backing paste emphasising the analytical results about its composition. Finally with respect to other indicators, I also examined the specific combination and quality of the gemstone or glass inlays.

To illustrate the presence or even the absence of the individual workshop affinities, I discussed the emblematic assemblages of the 5th century Carpathian Basin: the grave goods from Regöly, "Bakodpuszta” (Dunapataj-Bödpuszta), Gáva and "Beregvidék" (area of Beregovo), the Szilágysomlyó (Şimleu Silvaniei) treasure and the ritual deposits from Nagyszéksós and Bátaszék. I also dealt with the buckles from Lébény, Alcsút and the Eggers-collection, the bracelets from Beregszász (Beregovo) and an unknown site, as well as a stray brooch said to be found in Szilágysomlyó in detail. Identifying their materials technological characteristics facilitated discerning the items produced in the same workshop. Finally in case of the Bakodpuszta-type bracelets and fingerings, the bird brooch from "Beregvidék" and various artefacts from Gáva I also attempted to localise the production area.

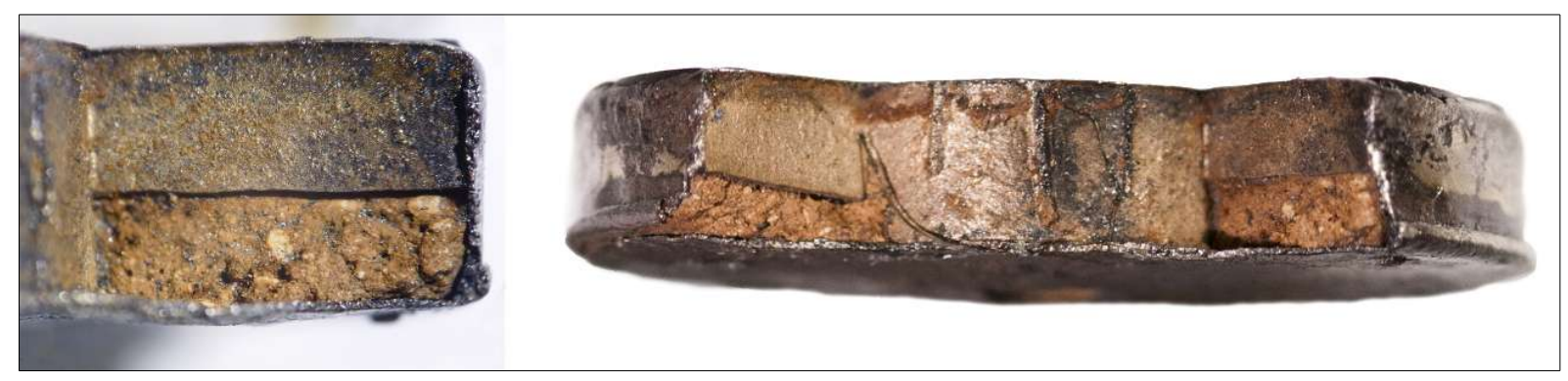

Fig. 23. Semi-suspended standard cloisonné technique on the disc brooch from Szentendre, grave 29 (Photo: E. Horváth).

Regarding the hammered-and-soldered silver artefacts decorated with standard cloisonné technique, I considered only one structural feature as a possible indicator for closer workshop affinities: the use of the semi-suspended standard cloisonné technique (Fig. 23). I suggested that the artefacts representing this special practice were produced in the same workshop. However, I emphasised that in order to resolve this question a comprehensive comparative analysis would be needed on their backing paste. When comparing the main components known to constitute the pastes I did not exclude the possibility that the production of the hammered-and-soldered silver jewellery was related to a common area. Neither the construction nor specific tool-marks did indicate any further relationships so far.

Cloisonné works - dated to the turn of the 5th-6th century and the first two thirds of the 6th century - seem to be homogenous both in their typology and ornamentation. However, in view of an unusual construction and the consequent use of diverse base-metals I could clearly discern a special group of cloisonné jewellery. This group includes brooches and 
buckles made by the suspended cloisonné technique (Fig. 4b, Fig. 24). Considering their relatively scanty occurrence and revealing the unique features of their production I proposed that they have common origins in a smaller or broader scale. Based on the comparative analyses of their ornamentation, their technology and their material, I suggested that at least three different goldsmiths produced eleven pieces of the investigated material. It is still an open question if these goldsmiths worked in different or in the same workshop(s). These products represent various types of artefact; however, the three designs differ considerably and consequently from each other. In fact, I could identify the specific marks of three particular craftsmen independently from the typological and general materials technological characteristics. $^{20}$

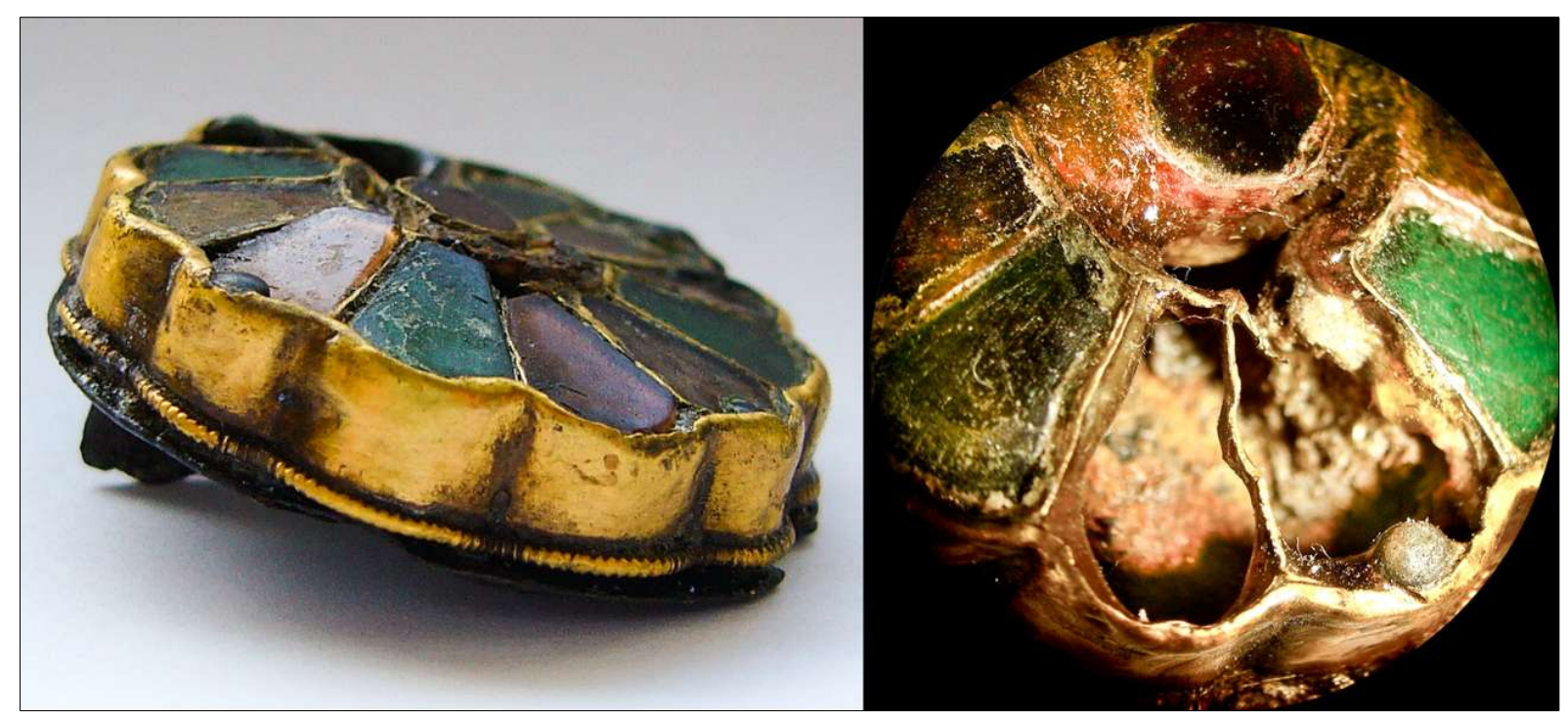

Fig. 24. Suspended cloisonné technique on the rosette brooch from Hegykő, grave 18 (Photo: E. Horváth).

Apart from the Pannonian finds I attributed several other artefacts to the three goldsmiths that were unearthed in Southern Germany and Northern Italy. The eastern- and westernmost sites of their occurrence, Hegykő in Hungary and Andernach in Germany, suggested labelling this trend as Hegykö-Andernach group (Fig. 25). The concentration of the relevant archaeological sites implies that the goldsmiths worked beyond the Carpathian Basin. Based on the available results I suggested that the activity of the three goldsmiths ran relatively close to each other, in the Alamannic-Baiuvarian territory. ${ }^{21}$

With respect to the Mediterranean-type exemplars of the simple copper-alloy buckles, I highlighted the characteristics of the assembly elements, the backing paste and in some cases the composition of the solder as well as the typical combination of the base-alloy and the inlays. I could show the presence or absence of the different degree of workshop affinities and made an attempt to discern the production areas in a wider sense as well. In the majority of the buckles I suggested a Mediterranean origin; I considered the local production (Carpathian Basin) only in case of the buckle from Szolnok-Zagyva-part (VII/16 grave).

As for the localisation of the workshops, the achieved greatest result is related to the buckle from Rákóczifalva, where gypsum - the base-mineral of the backing paste - proved to be 
fundamental. ${ }^{22}$ The presence of this type of paste in other artefacts suggested its use in the practice of several workshops in the same geographical region working on different quality and for different purposes. The identification of the brass-alloy, the preserved fragment of red glass inlay and the tiny chip of blue glass mixed into the bright mass suggested an Eastern-Mediterranean origin. ${ }^{23}$ I interpreted the enrichment of the various Mediterranean, Eastern-Roman elements in the 5th-6th century material culture as the result of the military alliance between the Gepidic Kingdom and the neighbouring Early Byzantine Empire. ${ }^{24}$

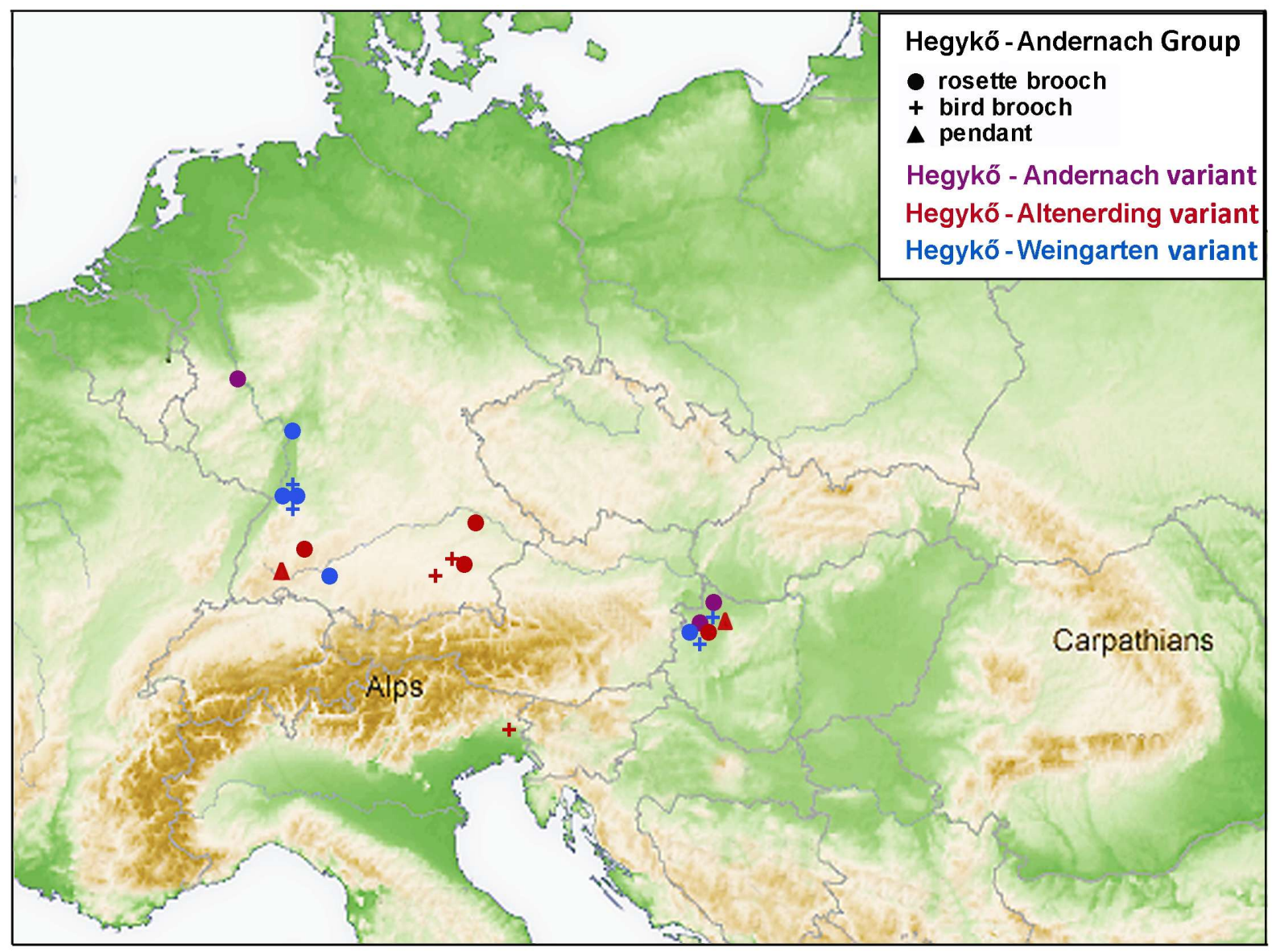

Fig. 25. The distribution map with the artefacts of the Hegykő - Andernach group (after HoRváth 2012a, Fig. 6a).

Concerning the bird head copper-alloy buckles, the nature of their manufacture did not allow us to reveal any indicators for the individual relationships. The base-form and the construction of the buckles under analyses proved to be identical and the workmanship of their technical details seemed to be equally mediocre. Based on my observations two different explanations could be taken into account behind this phenomenon. On the one hand, these pieces of metalwork could be derived from the same workshop or goldsmith. On the other hand, specific marks indicating different manufacturing sites could remain obscure in the absence of analytical measurements. Without further examinations only moderate conclusions could be drawn supposing that these finds originated from the same production area. 
Apart from some rare occasions, the construction of the cast-and-carved silver or copper artefacts did not facilitate the reconstruction of any kind of workshop affinity. Differences and similarities in the workshop practice were manifested mostly in the use of specific tools. In case of the analysed artefacts I was primarily concerned with the punchmarks, the features of the chip carving decoration made with the help of the so called auxiliary mould, ${ }^{25}$ as well as the pattern of the backing foils made by die.

Comparative analyses led to new results concerning both the artefacts unearthed in the same site and assemblage and the exemplars representing different assemblages. Among others I discussed the workshop affinities related to the various cast pieces from Gáva and Zsibót-Domolospuszta as well as the brooches from Vörs and Keszthely in particular. Another case study about the buckles from Kapolcs and Nagyvárad (Oradea) proved that artefacts produced in the same workshop - even approximately at the same time - could have reached regions situating quite far from each other.

Similarly to the previous groups, analogues pieces found beyond the Carpathian Basin were also discussed as case studies. By employing complex technological and compositional analyses it could be proved and disproved whether the artefacts were produced at the same time and the same site. Regional workshop affinities of some groups of artefacts that represent the same formal or technological features were discussed. Extending the region of the relevant finds, interpretation about the rhombic belt buckles, the bow brooches and eagle head belt buckles of the Gepidic Period as well as the bow- and various S-shape brooches of the Langobardic Period were elaborated. In my dissertation not only their relative relationship was aimed to be reconstructed but also in some cases their production area was attempted to be localised, focusing primarily on the role and activity of the local goldsmiths in the regions of the Great Plain and the Transdanubia.

\section{References}

Adams, N. 2000: The Development of Early Garnet Inlaid Ornaments. In: BÁLINT, Cs. (Hrsg.), Kontakte zwischen Iran, Byzanz und der Steppe in 6-7. Jahrhundert. Varia Archaeologica Hungarica 10. Budapest, 13-53.

Arrhenius, B. 1977: Metallanalysen von Goldbrakteaten. Vorbericht über ein laufendes Forschungsprojekt. Frühmittelalterliche Studien 11, 74-84.

Böнme, H. W. 1974: Zum Beginn des germanischen Tierstils auf dem Kontinent. In: KossAcK, G. UlBert, G. (Hrsg.), Studien zur vor- und frühgeschichtlichen Archäologie. Festschrift für foachim Werner. München, 295-308.

Böнme, H.W. 1986: Das Ende der Römerherrschaft in Britannien und die angelsächsische Besiedlungs Englands im 5. Jahrhundert. Jahrbuch des Römisch-Germanischen Zentralmuseums 33, 469-574.

Calligaro, T. - Périn, P. - Vallet, F. - Poirot, J.-P. 2008: Contribution à l'étude des grenats mérovingiens (Basilique de Saint-Denis et autres collections du Musée d'Archéologie Nationale, diverses collections publiques et objects fouilles récentes). Antiquités Nationales 38, 111-144.

25 This mould served as a negative for making wax model related to the process of the lost wax casting. Archaeological remains of this type of artefact in the Carpathian Basin are known only from the Roman Period so far. For further example from the Migration period see e.g. STEUER 1994, 133, fig. 6.6. This kind of moulds is made of clay but it does not bear the traces of any secondary thermal treatment (i.e. casting of hot metal). I am grateful for Nikoletta Sey who has drawn my attention to the presence of the auxiliary moulds, I am referring her terminology; see SEY 2013. 
Christie’s 1996: Christie’s Fine Antiquities. 11 December 1996.

Costin, C. L. 1991: Craft specialization. Issues in defining, documenting, and explaining the organization of production. Archaeological Method and Theory 3, 1-56.

Craddock, P. T. - Cowell, M. - Hook, D. - Hughes, M. - La Niece, S. - Meers, N. 2010: Change and stasis: the technology of Dark Age metalwork from the Carpathian Basin. British Museum Technical Research Bulletin 4, 55-65.

Gilg, H. A. - Gast, N. - Calligaro, T. 2010: Vom Karfunkelstein. In: Wamser, L. (Hrsg.), Karfunkelstein und Seide. Neue Schätze aus Bayerns Frühzeit. Ausstellungskataloge der archäologischen Staatssammlung 37. München, 87-100.

Hawkes, S. C. 1984: The Amherst Brooch. Archaeologia Cantiana 101, 129-151.

HASEloff, G. 1973: Zum Ursprung der germanischen Tierornamentik - die spätrömische Wurzel. Frühmittelalterliche Studien 7, 406-442.

Haseloff, G. 1981: Die germanische Tierornamentik der Völkerwanderungszeit Band I-III. Berlin.

Haseloff, G. 1990: Germanische und östliche Tierornamentik im Donauraum. In: Wamers, E. Metternich, W. - Kluge-Pinsker, A. (Hrsg.), Frankfurter Beiträge zur Mittelalter-Archäologie II. Bonn, 27-47.

Heinrich-TamÁska, O. 2005: Deutung und Bedeutung von Salins Tierstil II zwischen Langobardia und Avaria. In: Pohl, W. - Erhart, P. (Hrsg.), Die Langobarden. Herrschaft und Identität. Wien, 281-300.

Horedt, K. - Protase, D. 1972: Das zweite Grab von Apahida. Germania 50, 174-220.

HoRvÁth, E. 2006: A langobard ékkő- és üvegberakás technológiai sajátosságainak vizsgálata a várpalotai és jutasi fibulákon (The Technological Analysis of the Langobard Precious Stone and Glass Inlay on the Brooches of Várpalota and Jutas). Veszprém Megyei Múzeumok Közleményei $24,49-66$.

HorvÁth, E. 2008: Régi leletek - új eredmények. Ékkövek és egyéb ásványi anyagok a langobardok ötvöstárgyaiban (Alte Funde - neue Ergebnisse. Edelsteine und andere Mineralien in Kunstschmiedegegenständen der Langobarden). In: Molnár, A. - NAGy, A. - ToмкA, P. (eds.), föttek - mentek. Langobardok és avarok a Kisalföldön. Kiállításvezetö (Sie kamen und gingen. Langobarden und Awaren in der Kleinen Tiefebene. Ausstellungsführer). Győr, 55-71.

Horváth, E. 2010: Provenance and technology study on a collection of loose garnets from a late 5th century Gepidian grave in Northeast Hungary. In: Zaharia, L. - Kis, A. - Topa, B. - PAPP, G. - Weiszburg, T. (eds.), Abstracts Volume of IMA2010, the 20th General Meeting of the International Mineralogical Association 21-27 August, Budapest, Hungary. Acta Mineralogica-Petrographica Abstract Series 6. Szeged, 117.

HoRvÁth, E. 2011: Ékkőberakásos ötvösművészet a pannoniai langobard korszakban. Régészeti kérdések, archeometriai módszerek. In: Bíró, Sz. - ToмкA, P. (eds.), „Hadak Útján” - A népvándorlás kor fiatal kutatóinak XIX. Konferenciája. Győr-Moson-Sopron Megyei Múzeumok Igazgatósága Tanulmányok 3. Győr, 125-139.

Horváth, E. 2012a: Cloisonné Jewellery from the Langobardic Pannonia. Technological Evidence of Workshop Practice. In: Kazanski, M. - Ivanisević, V. (dir.), Ponto-Danubian territory during the Great Migration Period (5th-6th centuries). Paris, 207-242. 
Horváth, E. 2012b: A Egy „mediterrán” övcsat Rákóczifalva-Kastélydombról. A műhelykérdés archeometriai megközelítése (Mediterranean buckle from Rákóczifalva-Kastélydomb. The archaeometrical aspect of the localization of production area). In: VIDA, T. (ed.), Thesaurus Avarorum. Régészeti Tanulmányok Garam Éva tiszteletére (Archaeological Studies in Honour of Éva Garam). Budapest, 319-342.

Horváth, E. - Bendő, Zs. 2011: Provenance study on a collection of loose garnets from a Gepidic period grave in Northeast Hungary. Archeometriai Mühely 8/1, 17-32.

Horváth, E. - May, Z. - S. KovÁcs, J. - Tóth, M. 2009: An Early Medieval buckle with cloisonné decoration the localization of workshop area by archaeometrical investigation. Archeometriai Mühely 6/4, 15-30.

Horváth, E. - Bendő, Zs. - MAY, Z. 2013: One hundred year later... Characteristics of materials technology and workshop affinities of the polychrome metalwork from Gáva (North-East Hungary). In: Hardt, M. - Heinrich-Tamáska, O. (Hrsg.), Macht des Goldes, Gold der Macht. Herrschafts- und Jenseitsrepräsentationen zwischen Antike und Frühmittelalter im mittleren Donauraum. Forschungen zu Spätantike und Mittelalter, Bd. 2. Weinstadt, 251-280.

Kazanski, M. - Mastykova, A. - PÉrin, P. 2002: Byzance et les royaumes barbares d'Occident au début de l'époque mérovingienne. In: TejRAL, J. (Hrsg.), Probleme der frühen Merowingerzeit im Mitteldonauraum. Spisy archeologického ústavu AV ČR Brno 19. Brno, 159-194.

Kendrick, T. D. 1933: Polychrome Jewellery in Kent. Antiquity 7, 429-453.

Kent, J. P. C. 1972: Gold Standards of the Merovingian Coinage, A.D. 580-700. In: Hall, E. T. - MetCALF, D. M. (eds.), Methods of Chemical and Metallurgical Investigation of Ancient Coinage. Royal Numismatic Society Special Publication 8, 69-74.

KIss, A. 1991: Die „Barbarischen” Könige des 4-7. Jahrhunderts im Karpatenbecken, als Verbündeten des Römischen bzw. Byzantinischen Reiches. Communicationes Archaeologicae Hungariae, $115-128$.

LA NiECE, S. 1983: Niello: a historical and technical survey. Antiquaries fournal 63/2, 279-297.

Northover, J. P. - La Niece, S. 2009: New thoughts on niello. In: Shortland, A. J. - Freestone, I. C. - Rehren, Th. (eds.), From mine to microscope: advances in the study of ancient technology. Oxford, 145-154.

Oddy, W. A. - Meyer, V. E. G. 1986: The analysis of the gold finds from Helgö and their relationships to other Early Medieval gold. In: Lundström, A. - Clarke, H. (eds.), Excavations at Helgö X. Coins, Iron and Gold. Stockholm, 153-178.

Oddy, W. A. - Bimson, M. - LA Niece, S. 1983: The composition of niello decoration on gold, silver and bronze in the antique and mediaeval periods. Studies in Conservation 28, 29-35.

QuAst, D. - Schüssler, U. 2000: Mineralogische Untersuchungen zur Herkunft der Granate merowingzeitlicher Cloisonnéarbeiten. Germania 78, 75-96.

RIEDERER, J. 2002: The use of standardised copper alloy in Roman metal technology. In: GiumliAMAIR, A. (ed.), I bronzi antichi. Produzione e technologia. Atti del XV Congresso Internazionale sui Bronzi Antichi, Grado/Aquileia 2001. Montagnac, 284-291.

Roтн, H. 1980: Almandinhandel und -verarbeitung im Bereich des Mittelmeeres. Zum archäologische Befund und der schriftlichen Überlieferung in der Spätantike und in frühen Mittelalter. Beiträge zur Allgemeinen und Vergleichenden Archäologie 2, 309-335.

ScнöN, M. D. 2005: Prunk und Pracht im hölzernen Sarg. Archäologie in Deutschland 2005/3, 28-30. 
SEY, N. 2013: A pannoniai római kori bronzmúvesség mühelykérdései. $\mathrm{PhD}$ thesis, manuscript. Budapest.

Stark, R. 1999: Die Fibeln. In: Seipel, W. (Hrsg.), Barbarenschmuck und Römergold. Der Schatz von Szilágysomlyó. Budapest, 145-149.

Steuer, H. 1994: Handwerk auf spätantiken Höhensiedlungen des 4./5. Jahrhunderts in Südwestdeutschland. In: Nielsen, P. O. - Randsborg, K. - Thrane, H. (Hrsg.), The Archaeology of Gudme and Lundeborg. Arkæologiske Studier 10. Kobenhavn, 128-144.

SzÉKely, M. 2008: Kereskedelem Róma és India között. Szeged.

Wolters, J. 1996: Niello im Mittelalter. Löten im Mittelalter. Drahtherstellung im Mittelalter. In: Lindgren, U. (Hrsg.), Europäische Technik im Mittelalter: 800 bis 1200. Tradition und Innovation. Ein Handbuch. Berlin, 169-186, 187-203, 205-216.

Zaseckaja, I. 1999: Les Steppes pontiques à l'époque hunnique (question de chronologie). In: Tejral, J. - Pilet, Ch. - Kazanski, M. (dir.), L’Occident romain et l'Europe centrale debut de l'époque des Grandes Migrations. Brno, 341-365. 